
12

\title{
Sample treatments prior to capillary electrophoresis-mass spectrometry
}

Javier Hernández-Borges ${ }^{1 *}$, Teresa M. Borges-Miquel ${ }^{1}$, Miguel Ángel Rodríguez-Delgado ${ }^{1}$ and Alejandro Cifuentes ${ }^{2 *}$

${ }^{1}$ Department of Analytic al Chemis try, Nutrition and Food Science, Univers ity of La Laguna, Avda. Astrofísico Fco. Sánchez s/n, 38071 La Laguna, Tenerife, Spain

${ }^{2}$ Department of Food Analysis, Institute of Ind ustrial Fermentations (CS IC), Juan de la Cierva 3, 28006 Madrid, Spain

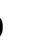

(1) .

17

Correspondence: Dr. Alejandro Cifuentes, Institute of Industrial Fermentations (CSIC), Juan de la Cierva 3, E-28006 Madrid, Spain. E-mail: acifuentes@ifi.csic.es. Fax: +34-91-5644853. Dr. J. Hernandez-Borges, Department of Analytical Chemistry, University of La Laguna, 38071 La Laguna, Tenerife, Spain. E-mail: jhborges@ull.es 
1

2

3

4

5

6 5

\section{Summary}

(

3

Sample preparation is a crucial part of chemical analysis and in most cases can become the bottleneck of the whole analytical process. Its adequacy is a key factor in determining the success of the analysis and, therefore, careful selection and optimization of the parameters controlling sample treatment should be carried out. This work revises the different strategies that have been developed for sample preparation prior to capillary electrophoresis-mass spectrometry (CE-MS). Namely, the present

work presents an exhaustive and critical revision of the different samples treatments used together with on-line CE-MS including works published from January 2000 to July 2006.

2

Keywords: Capillary electrophoresis/ Mass spectrometry/ CE-MS/ Sample pretreatment/ Couplings/ Hyphenated techniques/ Review 


\section{Contents}

2
1. Introduction.

2. Sample treatments.

2.1 Liquid-liquid extraction.

2.2 Solid-phase extraction.

2.3 Solid-liquid extraction.

2.4 Solid-phase microextraction.

2.5 Pressurized liquid extraction.

2.6 Other procedures.

3. Microfluidic devices.

4. Use of stacking techniques in CE-MS.

5. Conclusions and future outlook. 
1

2

3

4

5

\section{Introduction.}

(n)

It is generally assumed that in order to provide an adequate chemical analysis any analytical method must include the following steps: sampling (sample must be representative of the object under investigation), sample preservation (sample should be kept stable until the analysis in completed), sample preparation, sample analysis per se and data treatment. Often, one of the the bottlenecks of this analytical process is sample preparation since it is usally a time-consuming and laborious step. The purpose of any sample preparation is the clean-up of the sample and/or the extraction, enrichment or preconcentration of the analytes, improving in this way the quality of the analytical results obtained. However, it has to be considered that any sample treatment will depend on both the sample nature and the following analytical technique that is going to be employed, requiring an almost case-by-case development. Therefore, no universal sample preparation is available.

(1)

The choice and optimization of a suitable sample pretreatment is not easy, especially with highly complex sample matrices like biological fluids (plasma, serum, whole blood, urine, etc.) or other natural matrices including e.g., foods, plant extracts or environmental samples. Ideally, sample preparation should be as simple as possible, not only because it will reduce the time required, but also because the greater the number of steps, the higher the probability of introducing errors. If possible, sample preparation should be carried out without loss of the analytes (or with the minimum loss) while eliminating as many interferences as possible from the matrix. Finally, it should also include, when necessary, a suitable dilution or concentration of the analytes in order to obtain an adequate concentration for the subsequent analysis. Sometimes, it may also include the transformation of the analytes into different chemical forms that can make 
1 easier e.g., their separation or detection.

2

3

4

5

6

At the present time, developments in sample pretreatment strategies involve the use of new extraction materials, the use of automated protocols and/or its integration into miniaturized formats such as microchips or micrototal analysis sytems ( $\mu$-TAS) that should allow a rapid and sensitive analysis of the target analytes, especially in complex samples [1]. This research area has provided interesting and promising results and it will surely be one of the working areas in the future Analytical Chemistry.

Nowadays, the inherent advantages of the use of capillary electrophores is (CE) as separation technique are well known and can be summarized in high separation efficiency, low analysis time, high resolution power and low consume of samples and reagents. It is at the moment one of the premier analytical separation techniques for the analysis of biological compounds such as peptides, proteins and polynucleotides and has been applied with success to a great variety of analytes [2-6]. Its different separation modes (CZE, MEKC, ITP, etc.) have allowed facing the problem of the separation of either neutral or charged analytes based on different physico-chemical properties (charge/mass ratio, molecular weight, polarity or isoelectric point). Besides, the different detectors available (UV-Vis, laser induced fluorescence (LIF), mass spectrometry (MS), electrochemical, etc.) have also broadened its use and applications, although UV is the most widely used detector in CE equipments so far.

Nevertheless, the small capillaries used in CE separations accommodate only small volumes of sample, which require either the use of a suitable on-line or off-line preconcentration procedure or the use of a more sensitive detector like LIF or MS. In this regard, MS gives information on the molecular weight of the analytes and enables the separation of co-migrating molecules increasing selectivity and specificity acting as a second dimension. Furthermore, it also compensates the migration time variation that 
1 normally takes place in $\mathrm{CE}$ and provides unequivocal structural information via

2 fragmentation patterns that can be obtained for instance via $\mathrm{MS}^{\mathrm{n}}$ procedures. Therefore,

3 the on-line coupling of $\mathrm{CE}$ with MS gives rise to an impressive analytical tool that

4 combines the high resolution power and separation speed of CE with the high sensitivity

5 and selectivity of the mass spectrometer $[4,7,8]$. However, in ord er to take advantage

6 of the many possibilities derived from using CE-MS, it is of extreme importance a

7 suitable selection of $\mathrm{CE}$ separation parameters (buffer composition, $\mathrm{pH}$,

8 preconcentration procedures), ionization technique (usually electrospray, ESI), and ESI

9 and MS working parameters.

10 Thus, when developing a suitable CE-MS procedure several aspects have to be 11 taken into account. Only highly volatile buffers can be used and they are tipically an 12 aqueous or hydroorganic solution containing e.g., acetic acid, formic acid, ammonium 13 hydroxide at low concentrations. The use of non volatile components like cyclodextrins 14 (CDs), inorganic salts (e.g., containing sodium, phosphate, etc) or surfactants (as SDS) 15 are precluded since they are strong inhibitors of ESI efficiency, increase the noise and 16 reduce the sensitivity of the system. Different strategies have been proposed to 17 overcome this limitation including the partiall filling technique [9].

An additional consideration prior to use CE-MS is the development of suitable sample pretreatment procedures [10]. As an example, direct injection of samples with a high protein content results in short capillary longevity (proteins precipitate and can

21 irreversibly adsorb onto the silanol groups of the internal capillary wall) [11]. 22 Furthermore, despite the selectivity of the mass spectrometer, highly complex samples may also induce some ionization suppression or even a complete loss of the MS signal.

24 The objective of this work is, therefore, to provide an overview of the various samples 25 preparation protocols that have recently been proposed prior to on-line CE-MS covering 
1 relevant publications from January-2000 till July-2006.

2

3 2. Sample treatments.

5 In the time covered by the present review, different and interesting sample treatments prior to CE-MS have been proposed, which are sumarized in Table 1. As will

7 be next discussed, in some occasions a single or simple treatment procedure was not enough to ensure the correct analysis of the sample, requiring the use of several

9 consecutive sample treatments. In other cases, a single extraction or preconcentration

10 procedure was enough to reduce the sample complexity or to improve the LODs 11 achieved by CE-MS.

\subsection{Liquid-liquid extraction (LLE).}

This classical sample treatment allows the extraction of both trace analytes or macrocomponents. The selectivity and efficiency of the extraction process in LLE depends mainly on the election of the immiscible solvents, but other factors may also affect the distribution of the solute into both phases like the $\mathrm{pH}$, the addition of a complexation agent, the addition of salts (salting out effect), etc. Although the use of LLE alone provides goods results in terms of extraction efficiency and clean-up of the samples, it is often carried out in combination with other preconcentration procedures as it will clearly be seen in the subsequent examples and sections.

Rudaz et al [12] developed a CE-MS stereoselective analysis of tramadol and its main phase I metabolite in plasma after LLE with hexane-ethyl acetate $(80: 20, \mathrm{v} / \mathrm{v})$; samples were evaporated and redissolved in $0.01 \mathrm{M} \mathrm{HCl}$. The best enantioseparation 
1 was achieved using a coated polyvinyl alcohol (PVA) capillary and a $40 \mathrm{mM}$

2 ammonium acetate buffer at $\mathrm{pH} 4.0$ with $2.5 \mathrm{mg} / \mathrm{ml}$ sulfobutyl ether $\beta-\mathrm{CD}$ as the chiral

3 selector. To avoid the entrance of the CDs in the MS and, as a result, the loss of the MS

4 signal, the partial filling technique was applied.

5 Strickmann et al [13] developed an on-line capillary electrochromatography

6 (CEC)-ESI-MS method for the determination of etodolac and metabolites in urine.

7 CEC, although difficult to perform, is together with CZE the preferred CE mode for on-

8 line coupling with MS, because of the highly volatile buffers frequently used. The drug

9 and metabolites in urine could be analyzed by CEC-ESI-MS after LLE extraction using

10 an equal volume of ethyl-acetate and then evaporated and redissolved into the 11 separation buffer.

confirmation testing of morphine and related opioids in human urine by using a BGE containing $25 \mathrm{mM}$ ammonium acetate at $\mathrm{pH}$ 9. High analyte concentrations $(2-5 \mu \mathrm{g} / \mathrm{ml})$ could be monitored in plain and diluted urine samples without further treatment directly

by CE-MS. However, for the recognition of lower concentrations LLE at alkaline pH and solid phase extraction (SPE) were used and compared. Concerning the LLE procedure, a mixture of dichloromethane and dichloroethylene was used as extraction solvent. Mean recovery values ranged between 76 and $86 \%$ except for the metabolites nordihydromorphine and normorphine which were 14 and 25\% respectively. However, the SPE procedure using a mixed mode polymer phase (namely, Bond Elut and VacElut) provided higher recoveries, between 83 and $96 \%$ for all the compounds. For this particular application, SPE was shown to be more time consuming than LLE since an additional evaporation step was required to eliminate water from the eluate. 


\subsection{Solid-phase extraction (SPE).}

Sample preparation using SPE was firstly introduced in the mid-1970s, replacing LLE due to its simplicity, selectivity and the better LODs that it provides. Since then, SPE has gained a wide acceptance due to the ease of automation, high analyte recovery, extraction reproducibility, ability to increase selectively analyte concentration and commercial availability of many SPE devices and sorbents, including the use of molecular imprinted polymers (MIPs) $[15,16]$.

Concerning the use of SPE it is probably the most widely used sample pretreatment procedure prior to CE-MS. Recently, Hernández-Borges et al [17] have determined five triazolopyrimidine sulfoanilide herbicides (cloransulam-methyl, diclosulam, florasulam, flumetsulam and metosulam) in soy milk by SPE-CZE-MS using $\mathrm{C}_{18}$ cartridges. For this purpose, CE-UV and CE-MS instruments were used. To increase the sensitivity of the method, normal stacking mode (NSM) was also used for on-line preconcentration of the SPE extract, providing LODs down to $74 \mu \mathrm{g} / \mathrm{L}$. Mean recovery percentages ranged between 40 and 94\% with good separations when working with aqueous solutions and SPE-NSM-CE-UV as shown in Figure 1A. However, the use of SPE combined with NSM-CZE-UV for analysis of the mentioned pesticides in soy milk did not provide suitable results because of the high number of interferences from the sample matrix (see Figure 1B). In order to overcome this limitation CE-MS was used. Thus, the main ESI-MS parameters (nebulizer pressure, dry gas flow rate, dry gas temperature and sheath-liquid composition) were optimized by means of a central composite design. Optimum separation buffer was composed of $24 \mathrm{mM}$ formic acid and $16 \mathrm{mM}$ ammonium carbonate at $\mathrm{pH}$ 6.4, while the sheath-liquid was composed of acetonitrile:water $82.5: 17.5(\mathrm{v} / \mathrm{v})$ with $2 \%$ of TEA at $0.35 \mathrm{~mL} / \mathrm{h}$ flow rate. The 
1 combined use of SPE-NSM-CE-MS allowed the detection of these pesticides in soy

2 milk as can be seen in Figure 1C.

3 Peterson et al [18] developed a specific CE-ESI-TOF-MS method for the 4 determination of serotonin (5HT) and its precursos tryptophan (Trp) and 5-

5 hydroxytryptophan (5HTP) in human platelet rich plasma. Analytes were removed from

6 the plasma and preconcentrated by SPE using Oasis MCX columns with mean

7 recoveries between 71.6 and $95.3 \%$. Submicromolar LODs were obtained for standard

8 mixtures of all the compounds except for 5HTP which had LODs in the low micromolar

9 range. When the method was applied to the analys is of plasma extracts from healthy

10 volunteers as well as from pathological samples the levels of both 5HT and Trp were

11 determined while 5HTP was not found present in any of the samples. In a previous

12 work of the same group [19] also a CE-ESI-TOF-MS method was used for the

13 determination of catecholamines (dopamine, norepinephrine and epinephrine) and their

14 O-methoxylated metabolites (3-methoxytyramine, normetanephrine, metanephrine) in

15 urine. In this case the capillary was coated with polyvinyl alcohol and the injection of

16 the samples was carried out electrokinetically. Catecholamin es and metanephrines were

17 removed from the urine samples and preconcentrated by SPE using cation-exchange

18 sorbents (Oasis $\mathrm{MCX}$ ) with mean recovery values over $80 \%$ for all the analytes, except

19 for epin ephrine (75\%).

20 Vuorensola et al [20] have also analyzed eight catecholamines in aqueous and

21 alcoholic (ethanol, methanol and 1-propanol) non-aqueous solutions by CE-MS but in

22 this case using sheathless nanospray coupling. A comparison was made between

23 different separation electrolytes for the separation of these compounds. Although non-

24 aqueous media (in methanol) was more efficient than water, both methods were applied

25 to the analysis of urine samples extracted with Oasis HLB cartridges using a previously 
1 developed protocol [21]. The sensitivity of the non-aqueous nanospray method (0.48-

$2 \quad 1.30 \mu \mathrm{M}$ ) was only slightly better than that of a previous aqueous method using coaxial

3 sheath-liquid coupling [22].

SPE procedures are often used after the LLE or solid-liquid extraction of the

5 analytes assisted or not by ultrasounds, microwaves, etc. Rodríguez et al [23] have used

$6 \quad \mathrm{C}_{8}$ cartridges for the extraction of pesticides thiabendazole and procymidone from fruits

7 (apples, grapes, oranges, pears, strawberries) and vegetables (tomatoes) after a suitable

8 sonication of the homogenized samples with methanol:water 1:1 for $15 \mathrm{~min}$. Separation

9 was achieved using a buffer of formic acid-ammonium formate at $\mathrm{pH} 3.5$ with $2 \%$ of

10 methanol (the sheath-liquid was the same as the separation buffer). LOQs of the SPE-

11 CE-MS procedure (using also a stacking technique) ranged between 0.005 and 0.05

$12 \mathrm{mg} / \mathrm{kg}$, with mean recovery values of 64 and $75 \%$ for thiabendazole and procymidone,

13 respectively.

Recently, Juan-García et al [24] have also extracted six pesticides (thiabendazole, pyrifenox, pirimicarb, pyrimethanil, procymidone and dinosed) from 16 peaches and nectarines with a mixture water:acetone $1: 1(\mathrm{v} / \mathrm{v})$ prior to their SPE 17 extraction with $\mathrm{C}_{18}$ cartridges before their CE-MS or CE-MS/MS determination. In this case, a buffer consisting of $0.3 \mathrm{M}$ ammonium acetate-acetic acid $\mathrm{pH} 4$ in $10 \%$ methanol (the sheath-liquid had the same composition) was used. Recovery percentages ranged between 58 and 99\% with relative standard deviation values (RSD \%) between 9 and 19\%. Under optimized CE-MS/MS conditions the minimum detectable levels of the six pesticides in spiked samples were between 0.01 and $0.05 \mathrm{mg} / \mathrm{kg}$.

Sentellas et al [25] described the optimization of a clean-up and preconcentration procedure for the determination of fifteen heterocyclic amines in human urine samples. 
1 detection. Peak intensities obtained after clean up for both sorbents were similar for

2 most of the amines; however, Oasis MCX cartridges were selected because they

3 provided slightly better recoveries for some of the amines. When urine samples were

4 analyzed, interferences preventing the analytes identification were observed with both

5 cartridges, that is why a LLE procedure using dichloromethane was used. The

6 optimized clean-up procedure together with a previously published field-amplified

7 sample injection (FASI)-CE-MS method [26] was used for the quantification of

8 heterocyclic amines in hydrolyzed spiked human urine, obtaining LOD down to 0.3

$9 \mathrm{ng} / \mathrm{mL}$.

10 As it has been previously indicated, BGE solutions as well as sheath-liquid 11 compositions should be volatile enough in CE-MS. In spite of this limitation, several 12 works have appeared in which CDs are used as components of the separation electrolyte 13 to analyze SPE extracts by CE-MS [27-29]. For instance, Servais et al [29] have used 14 nonaquous $\mathrm{CE}$ (NACE)-ESI-MS with heptakis(2,3-di- $O$-acetyl-6- $O$-sulfo)- $\beta$ 15 cyclodextrin (HDAS- $\beta-C D)$ in the BGE for the enantioselective determination of low 16 concentrations of salbutamol in SPE extracts from human urine. The selected separation 17 electrolyte consisted of $10 \mathrm{mM}$ ammonium formate and $15 \mathrm{mM}$ HDAS- $\beta$-CD in

\section{$\underline{2.3 \text { Solid-liquid extraction. }}$}

Extraction from solid matrices has to be carried out after an adequate 
1 homogenization or trituration of the sample, which can be enhanced (as well as the

2 extraction efficiency) by lyophilization or by the use of liquid-nitrogen. The extraction

3 of organic compounds, for example, involve the desorption of the analytes from the

4 sample matrix and their later dissolution into the solvent, which is controlled by the

5 solubility, mass transfer and matrix effects. Extraction can be improved by either

6 assisting the process with ultrasounds, microwaves, etc. Sonication, for example, helps

7 in the homogenization of the sample and, consequently, it can be used for the rapid an

8 easy extraction of analytes from solid samples. Thus, Groom et al [27] have analyzed

9 nitroaromatic and cyclic nitramine contaminants originated from military explosives

10 and propellants (TNT, TNB, RDX, HMX, CL-20) in soil and marine sediments using

11 sonication with acetonitrile together with sulfobutylether- $\beta$-cyclodextrin (SB- $\beta-C D)$

12 assisted CE-ESI-MS. In this work, it was also stated that the presence of highly charged

13 SB- $\beta$-CDs may affect the identification of target explosive analytes. Optimum BGE

14 consisted of $10 \mathrm{mM}$ SB- $\beta-\mathrm{CD}$ and $10 \mathrm{mM}$ ammonium acetate at $\mathrm{pH} 6.9$ using

15 acetonitrile alone as sheath-liquid.

16 Feng et al [30] have analyzed several alkaloids (aconitine, hypaconitine, 17 mesaconitine, brucine, strychnine, icajine, atropine, novacine) and their hydrolysis 18 products in Chinese medicine preparations (Maqianzi, the seed of Strychnos pierrian, 19 and Wutou, aconite root of Radix aconiti praeparata) by CE-ESI-MS. Pulverized 20 samples were immersed in methanol overnight and afterwards ultrasonicated for $30 \mathrm{~min}$ 21 prior to their CE-MS determination. Goodwin et al. [31] were able to separate and 22 determine herbicides glyphosate and glufosinate and their derivatives 23 (aminomethylphosphonic acid and methylphosphinicpropionic acid) in wheat samples 24 using CE-ESI-MS with a sheathless interface. In this case wheat samples were extracted 25 in a mixture of water-acetone 1:1 with magnetic stirring for $1 \mathrm{~h}$. The separation buffer 
1 was $1 \mathrm{mM}$ ammonium acetate/acetic acid at pH 6.3 in a mixture methanol:water (50:50,

$2 \mathrm{v} / \mathrm{v})$. The best reproducibility in terms of migration times and peak areas was obtained

3 using a capillary coated with linear polyacrilamide. The extract was directly injected in

4 the CE system and the final LOD was $1 \mu \mathrm{M}$ in water and $2.5 \mu \mathrm{M}$ in the wheat water-

5 acetone extract.

6 Suomi et al [32] determined five neutral irioid glycosides (cyclopentanol

7 monoterpene derivatives) in plant samples by micellar electrokinetic chromatography

8 (MEKC) using SDS as surfactant. The separation system was coupled via a coaxial

9 sheath-liquid flow ESI interface to a MS using the partial filling (PF) technique to avoid

10 the entrance of the micelles in the MS. The separation, which was optimized by MEKC-

$11 \mathrm{UV}$, was achieved by using a BGE consisting of $100 \mathrm{mM}$ SDS in $20 \mathrm{mM}$ ammonium

12 acetate at $\mathrm{pH} 9.5$ (Figure 2). The compounds were detected as lithium adducts by the

13 addition of $1.0 \mathrm{mM}$ lithium acetate to the sheath-liquid (water-methanol 50:50, v/v).

14 The extraction of the samples was carried out with boiling water for $60 \mathrm{~min}$ of the

15 crushed dry leave samples (after $40 \mathrm{~min}$ at room temperature to wet the leaves

16 throughly), and after evaporation to dryness, the extract was redissolvend in Milli-Q

17 water and injected in the CE system. Catalpol, verbenalin, loganin and possibly 10-

18 cinnamoyl catalpol were found in the examination of seven plants species in the genera

19 Plantago, Veronica, Melampyrum, Succisa and Valeriana. LODs for the iridoid

20 glycosides ranged were $25 \mathrm{mg} / \mathrm{L}$ except for catalpol which was $50 \mathrm{mg} / \mathrm{L}$. In a second

21 work by the same group, Suomi et al [33] separated a higher number of irioid

22 glycosides (eleven) in several plants belonging also to the genera Plantago, Veronica,

23 Melampyrum, Succisa and Valeriana by PF-MEKC-ESI-MS. In this case, extraction of

24 the dry leave samples was also carried out with boiling water for $60 \mathrm{~min}$.

25 Recently, Arráez-Román et al [34] have tested different liquid-phase extraction 
1 procedures to establish which could provide the highest content of polyphenols and

2 bitter acids from hop characterized by CE-MS (optimum BGE was $80 \mathrm{mM}$ ammonium

3 acetate at $\mathrm{pH}$ 10.5). For this purpose hop pellets were powdered and extracted with

4 different solvents like hexane, methanol, methanol:water, etc. by shaking. Among them,

5 the extraction with hexane to remove lipids, carotenoids and chlorophylls and later with

6 methanol (to extract sugars, organic acids and phenolic compounds) allowed the

7 detection of the highest number of compounds.

8

9

Juan-García et al [35] determined five quinolone residues (danofloxacin, enrofloxacin, flumequine, ofloxacin and pipemidic acid) in chicken and fish by CE-MS by solvent extraction of the minced muscle tissues. A sodium phosphate buffer at $\mathrm{pH}$ 7.0 was added to the spiked samples which were later extracted with dichloromethane (rotary shaking). The organic layers were then extracted with $0.5 \mathrm{M} \mathrm{NaOH}$. This aqueous phase was adjusted to $\mathrm{pH} 7$ and extracted with hexane to eliminate the fat and it was then passed through a $\mathrm{C}_{18}$ cartridge following a suitable SPE protocol. Mean recovery values of the whole procedure ranged between 45 and $99 \%$ for chicken samples and between 52 and $90 \%$ for fish samples. The proposed method is sufficiently sensitive to analyse these quinolone in both samples because the LOQs achieved (50 $\mathrm{ng} / \mathrm{g})$ were below the maximum residue limits $(100-200 \mathrm{ng} / \mathrm{g})$ established by the EU.

\subsection{Solid-phase microextraction (SPME).} commercially avaible in 1993 [36]. Since its development, SPME has been increasingly used since its setup is small and convenient, it can be used to extract analytes from very small samples, it provides a rapid extraction and transfer to analytical instrument and 
1 can be easily combined with other extration and/or analytical procedures improving in a

2 large extent the sensitivity and selectivity of the whole method.

3 The on-line coupling of SPME with CE has been described in several occasions

$4 \quad[37,38]$, however, the use of such coupling is still a non-resolved top ic because of the

5 very small injection volumes required in CE. As a result, SPME-CE analyses are

6 typically carried out in an off-line mode, by manually desorbing the analytes in an

7 appropriate organic solvent, and later introducing it into the CE system. Rodríguez et al.

8 [39] carried out the analysis of a group of pesticides (ioxynil, $o$-phenylphenol,

9 haloxyfop, acifluorfen, picloram) in fruit samples by using SPME prior to CE-MS. In

10 that work, the buffer used consisted of $32 \mathrm{mM} \mathrm{HCOONH}_{4} / \mathrm{HCOOH}$ at $\mathrm{pH} 3.1$ while the

11 sheath-flow was made of $32 \mathrm{mM}$ separation buffer with a $20 \%$ of methanol with 14

$12 \mu \mathrm{L} / \mathrm{min}$ flow. After testing different SPME fibers, the use of CW-TPR allowed the

13 extraction of these pesticides from water and fruit samples down to $0.02-5 \mathrm{mg} / \mathrm{kg}$

14 (LOQ).

15 Hernández-Borges et al. [40] tested different SPME fibers and CE-MS for the

16 extraction and quantitative determination of a group of pesticides (pyrimethanil,

17 pyrifenox, cyprodinil, cyromazine and pirimicarb) in orange and grape juices. The

18 buffer used consisted of a volatile aqueous solution containing $0.3 \mathrm{M}$ ammonium

19 acetate/acetic acid at $\mathrm{pH} 4$ while the sheath-liquid was made of a mixture

20 isopropanol:water $(65: 35, \mathrm{v} / \mathrm{v})$ at $0.22 \mathrm{ml} / \mathrm{h}$ flow. In this case, SPME parameters (e.g.

21 extraction time, sodium chloride percentage, $\mathrm{pH}$ and desorption time) were optimized

22 by means of a chemometrical approach. The best results were achieved by direct

23 immersion of a PDMS-DVB fiber which allowed achieving LODs of these pesticides at

24 concentrations down to $15 \mathrm{ng} / \mathrm{mL}$ in water samples and down to $40 \mathrm{ng} / \mathrm{mL}$ in fruit 25 juices. 
2 in-tube SPME [42] have not yet been combined with CE-MS.

3

$4 \quad 2.5$ Pressurized liquid extraction (PLE).

5

6

Pressurized liquid extraction (PLE), also called accelerated solvent extraction, is a sample preparation technique in which a solvent at elevated temperature and pressure is used as extractant. By adequately chosing the solvent, its temperature and pressure it is possible to control, among other factors, the dielectric constant of the extractant and with that the polarity of the compounds that can be obtained. Moreover, PLE works in an automatic way, it requires small amounts of solvents and low extraction times. Therefore, PLE can provide fast extractions and purifications allowing testing a high number of extraction conditions under controlled conditions.

The possibilities of the combined use of PLE and CE-MS were recently demonstrated by Herrero et al [43-45]. PLE-CE-MS was applied to the extraction and characterization of the main antioxidants (i.e., polyphenols) from rosemary [43] and the extraction and characterization of phycobiliproteins from the microalga Spirulina platensis $[44,45]$. In this latter case, a thorough optimization of both the PLE extraction conditions (including sonication of the sample prior to PLE) and CE-MS conditions had to be carried out, demonstrating that PLE-CE-MS can be a fast, automatic and highly informative method for natural products investigations [46].

\section{$\underline{2.6 \text { Other procedures. }}$}

Apart from the previosly described sample treatment procedures, Table 1 also 
1 shows different and interesting alternatives for this purpose. Thus, introduced in the

2 mid-nin eteenth century, soxhlet extraction has been one of the extraction methods more

3 used until the development of modern extraction techniques. The need of cooled,

4 condensed solvents for the extraction makes this technique a slow alternative (up to 24-

548 hours of extraction) with a very high consumption of organic solvents that have to be

6 evaporated, although with very high recoveries and also with multiple sample extraction

7 possibilities. Concerning its combination prior to CE-MS several approaches have

8 appeared [47-49]. Very recently, Edwards et al [48] have used soxhlet extraction in

9 combination with LLE and SPE for the characterization by CE-ESI-MS of secondary

10 metabolites (flavonoids) from the antihyperglycaemic plant Gen ista tenera. In this case,

11 air-dried and powdered plants were extracted in a soxhlet apparatus with ethanol. After

12 filtration and evaporation the residue was redissolved in water and extracted

13 successively with diethyl ether, ethyl acetate and butanol. After another evaporation and

14 redissolution of part of the extract a SPE procedure with $\mathrm{C}_{18}$ was carried out. Optimum

15 buffer was composed of water:2-propanol (95:5, v/v) containing $10 \mathrm{mM}$ ammonium

16 carbonate at $\mathrm{pH} 9.25$. The CE-MS study of the extract allowed the identification of five

17 flavonoid aglycones, five flavonoid-monoglycosides, two flavonoid-diglycosides, one

18 flavonoid-triglycoside, thee monoacetyl-flavonoids, one diacetyl-flavonoid and one

19 acetyl-flavono id-glycoside. Wahby et al [49] have also used soxhlet extraction for the

20 extraction of atropine (tropane alkaloid) and choline (quaternary base) in hairy root

21 cultures of Cannabis sativa L. Hairy root cultures were rinsed with tap and distilled

22 water, frozen in liquid nitrogen and lyophilized. The dry material was ground to a fine

23 powder and extracted in a soxhlet apparatus with $70 \%$ of aqueous methanol for $16 \mathrm{~h}$.

24 After cooling, the extracts were filtered and concentrated. Both compounds could be

25 determined in the samples with LODs of $18 \mathrm{mg} / \mathrm{L}$ for choline and $320 \mu \mathrm{g} / \mathrm{L}$ for atropine 
1 using a BGE of $20 \mathrm{mM}$ ammonium acetate at $\mathrm{pH} 8.5$ and a sheath-liquid composed of

$250: 50, \mathrm{v} / \mathrm{v} 2$ 2-propanol:water with $0.5 \%(\mathrm{v} / \mathrm{v})$ formic acid $0.18 \mathrm{~mL} / \mathrm{h}$.

3 The combination of automated sample preparation in CE is especially useful for

4 the analysis of complex samples [50] since it can improve the selectivity and sensitivity

5 of the determination as well as to decrease the time involved in the sample treatment

$6[50,51]$. One of the main lines of research in this area is the combination of flow

7 injection systems with CE and, in a less extent, with CE-MS. Thus, Santos et al [52]

8 reported a new method for the separation and detection of 9 biogenic amines by the

9 used of a flow manifold coupled to a CE-ESI-MS for the automatic filtration of the

10 samples and their insertion into the CE vials. The on-line filtration was carried out using

11 a flow injection system coupled to the CE instrument. The BGE was composed of 25

$12 \mathrm{mM}$ citric acid at $\mathrm{pH}$ 2.0. Two injection modes (hydrodynamic and electrokinetic) were

tested. Although electrokinetic injection provided better sensitivity, it was also found to give worse precision and linear range and, therefore, hydrodynamic injection was selected. The method allowed the detection of amines between 0.018 and $0.09 \mu \mathrm{g} / \mathrm{mL}$.

16 The method was applied to the determination of biogenic amines in red and white wines 17 with mean recovery values around $100 \%$.

The use of microwave radiation for sample pretreatment has attracted growing interest in the past few years and has yield a numerous amount of publications [53-56]. Microwave radiation provides a homegeneous and instant heating of the sample yielding into very quick and effective extraction/digestion and thus strongly decreasing sample pretreatment times. Van Lierde et al [57] used microwave-assisted acid digestion of porcine and human skin to extract chromium species from these samples. The mechanism of chromium transport through the skin and the relationship between chromium allergy and chromium species (in vitro permeation experiments) was studied. 
1 For this purpose, CE-was used with inductively coupled plasma-mass spectrometry

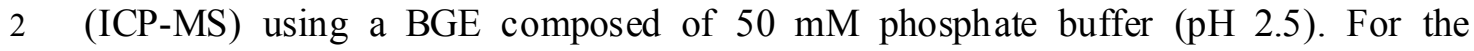

3 digestion of the samples, skin membranes were dried at $30^{\circ} \mathrm{C}$ for 24 hours, after that

$4 \mathrm{HNO}_{3}$ and $\mathrm{H}_{2} \mathrm{O}_{2}$ were added. Digestion was carried out at different microwave

5 intensities for a total of $25 \mathrm{~min}$. The LODs of the method ranged between 6 and $12 \mu \mathrm{g}$

6 of Cr per liter.

7

$8 \quad \underline{3}$ Mic roflu idic devices.

9

10

Clearly, development and/or use of microchip-CE are not objectives of this paper, however, microchip-CE devices deserve a special attention because they can automate sample preparation and, furthermore, they can integrate this step together with the chemical analysis under a single format that may allow a ultrarapid and sensitive analysis of the target analytes [58]. However, at the moment most of the applied aproaches suffer from several limitations regarding their fabrication, manipulation or the LODs that can be achieved. This can explain the very low number of publications found showing the on-line coupling of microchip-CE with MS.

A recent application of a microbead-packed polydimethylsiloxane (PDMS) microchip with an integrated electrospray emitter for sample pretreatment prior to sheathless ESI-TOF-MS was presented by Lindberg et al [59]. This system was applied for the desalting and enrichment of six neuropeptides from a physiological solution. Figure 3 shows a schematic picture of the PDMS microchip design used in that work. Electrical contact for the sheathless ESI was achieved by coating the integrated emitter with a conductive graphite powder after applying a thin layer of PDMS as glue. Both the coating and the bond of the PDMS structures were found to have a very good 
1 durability (a continuous spray was obtained over 800 h). Another PDMS microfluidic

2 system was previously developed by the same group [60] and applied to the analysis of

3 peptides but in this case only sample injection, separation and ESI emitter structures

4 were integrated in a single platform. As found in the literature, PDMS microchips with

5 an integrated ESI-emitter have been fabricated using different principles [61-66]. As an

6 example, Dahlin et al [62] presented a PDMS-based microchip for in-line SPE-CE with

7 an integrated electrospray emitter tip coupled to a TOF-MS. The chip was fabricated in

8 such a way that mixed PDMS was cast over steel wires in a mold. The removed wires

9 defined $50 \mu \mathrm{m}$ cylindrical channels where fused silica capillaries were inserted. The

10 microchip was fabricated in a two-level cross design. In one of these channels

11 hypercross-linked polystyrene beads acted as SPE sorbent for desalting. In this work,

12 six-peptide mixtures at different concentrations were dissolved in physiological salt

13 solutions and injected, desalted, separated and sprayed into the MS for the analysis.

14 LODs were in the femtomole levels.

68]. Wang et al [67] have proposed the use of a microfluidic device with a CE channel

connected to a MS (via an ESI interface) which contains a digestion bed on a monolithic

substrate to carry out the in-line protein digestion. The application of this device for the

$\underline{\text { rapid digestion, separation and identification of proteins was demonstrated for melittin, }}$

cytochrome $\mathrm{c}$ and bovine serum albumin. The rate and efficiency of the digestion was

$\underline{\text { related to the flow rate of the substrate solutions through the reactor. For cytochrome c }}$

and bovine serum albumin the digestion time was 3-6 min at room temperature, while

for melittin was $5 \mathrm{~s}$. Microdevices provide a convenient platform for automated sample

processing in proteomic applications. 


\section{Use of stacking techniques in CE-MS.}

2

3

Although strictly speaking the use of stacking techniques (except on-line SPE) cannot be considered part of the sample treatment, we would like to include a brief comment here about the use of these techniques together with CE-MS. On-line preconcentration strategies based on sample stacking [69-71], sweeping [72] and/or solid-phase extraction (SPE) [73-75] have shown their usefulness for improving the limits of detection (LOD) achieved by CE. Concerning the use of these techniques together with CE-MS they are not easy to apply and, in some cases, their use is limited. For instance, many of these preconcentration strategies involve the use of CDs, surfactants, and other non-volatile compounds that are precluded in CE-MS or can affect the stability of the electrical circuit in CE-ESI-MS. For example, the use of stacking with matrix removal (SWMR) is not possible in CE-MS since there is not outlet vial necessary in this case to reverse the polarity and to eliminate the sample matrix. In Table 1 it can be observed that these techniques are not widely applied in CEMS.

The use of the electrokinetic injection in the mode called field-enhancement sample injection (FESI) also called field-amplified sample injection (FASI) or fieldamplified sample stacking (FASS) is one of the most commonly stacking techniques in CE-MS, because, despite the presence of the siphoning effect that can take place, the sensitivity improvement can be high, although in this case only one type of charged analyte (cations or anions) can be introduced into the capillary [25, 26, 76-79].

Hernández-Borges et al [17] have used normal stacking mode (NSM) for the preconcentration of pesticides after their SPE extraction from soy milk samples. This technique is easy to apply because only a low conductivity matrix is required (which 
1 can be achieved by the use of organic solvent) since focusing takes places due to the

2 abrupt change in the local electric field between the sample matrix and the BGE. In this

3 case, the stack ing was achieved by injecting a high amount of the sample (up to $100 \mathrm{~s}$ at

$420 \mathrm{psi}$ ) dissolved in pure acetonitrile. This specific type of stacking is often called

5 acetonitrile stacking because of the good sensitivity improvement that the use of

6 acetonitrile alone in the sample matrix has provided, which has also been observed by

7 different authors [80-84].

8

\section{Conclusions and future outlook.}

Some current trends in the todays' sample pretreatment area are expected to continue in the future as important research areas within this attractive field of Analytical Chemistry. This is the case for the search of new extraction materials including the development of molecular imprinted polymers (MIPs) to adsorb specific analytes mimicking for instance immunorecognition. These new extraction materials

16 can play a definitive role in the development of completely automated analytical

17 processes able to provide information on analyte composition and concentration without

18 the intervention of the operator. In this regard, the integration of sample preparation devices into miniaturized formats (e.g., microchips, $\mu$-TAS) seem to be a very atractive way to achieve this goal while increasing even more the throughput and analysis speed of these methods. These future procedures combined with on-line stacking techniques and CE-MS can give rise to an ever more impressive and powerful analytical sys tem.

\section{Acknowledgements}


2 post-doctoral position. Authors are grateful to the AGL2005-05320-C02-01 Project

3 (Ministerio de Educacion y Ciencia) and the ALIBIRD-S-505/AGR-0153 Project

4 (CAM) for financial support of this work. 


\section{References}

2 [1] Y. Saito, K. Jinno, J. Chromatogr. A 1000 (2003) 53.

3 [2] C. Simó, C. Barbas, A. Cifuentes, Electrophoresis 24 (2003) 2431.

4 [3] J. Hernández-Borges, S. Frías-García, A. Cifuentes, M.A. Rodríguez-Delgado, J.

$5 \quad$ Sep. Sci. 27 (2004) 947.

6 [4] J. Hernández-Borges, C. Neusu $\beta$, A. Cifuentes, M. Pelzing, Electrophoresis 25

$7 \quad$ (2004) 2257.

8 [5] W. Kolch, C. Neusuß, M. Pelzing, H. Mischak, Mass Spectrom. Rev. 24(2005) 959.

9 [6] N.A. Guzmán, J. Stubbs, Electrophoresis 22 (2001) 3602.

10 [7] Ph. Schmitt-Kopplin, P. Frommberger, Electrophoresis 24 (2003) 3837.

11 [8] J. Ohnesorge, C. Neusüß, H. Wätsig, Electrophoresis 26 (2005) 3973.

12 [9] L. Valtcheva, M. Jamil, G. Petterson, S. Hjertén, J. Chromatogr. 638 (1993) 263.

13 [10] M. Gilar, E.S.P. Bouvier, B.J. Compton, J. Chromatogr. A 909 (2001) 111.

14 [11] J.R. Veraart, H. Lingeman, U.A.Th. Brinkman, J. Chromatogr. A 856 (1999) 483.

15 [12] S. Rudaz, S. Cherkaoui, P. Dayer, S. Fanali, J.L. Veuthey, J. Chromatogr. A 868 $16 \quad(2000) 295$.

17 [13] D.B. Strickmann, B. Chankvetadce, G. Blaschke, C. Desiderio, S. Fanali, J. 18 Chromatogr. A 887 (2000) 393.

19 [14] A.B. Wey, W. Thormann, J. Chromatogr. A 916 (2001) 225.

20 [15] E.H.M. Koster, C. Crescenzi, W. den-Hoedt, K. Ensing, G.J. de-Jong, Anal. Chem.

$21 \quad 73(2001) 3140$.

22 [16] J. Wu, X. Yu, H. Lord, J. Pawliszyn, Analyst 125 (2000) 391.

23 [17] J. Hernández-Borges, M.A. Rodríguez-Delgado, F.J. García-Montelongo, A. 24 Cifuentes, J. Sep. Sci. 28 (2005) 948.

25 [18] Z.D. Peterson, M.L. Lee, S.W. Graves, J. Chromatogr. B 810 (2004) 101. 
1 [19] Z.D. Peterson, D.C. Collins, C.R. Bowerbank, M.L. Lee, S.W. Graves, J.

2 Chromatogr. B $776(2002) 221$.

3 [20] K. Vuorensola, H. Sirén, R. Kostainen, T. Kotiaho, J. Chromatogr. A 979 (2002)

4179.

5 [21] K. Vuorensola, H. Sirén, J. Chromatogr. A 895 (2000) 317.

6 [22] K. Vuorensola, J. Kokkonen, H. Sirén, R.A. Ketola, Electrophoresis 22 (2001)

74247.

8 [23] R. Rodríguez, Y. Picó, G. Font, J. Mañes, J. Chromatogr. A 949 (2002) 359.

9 [24] A. Juan-García, G. Font, Y. Picó, Electrophoresis 26 (2005) 1550.

10 [25] S. Sentellas, E. Moyano, Ll. Puignou, M.T. Galcerán, J. Chromatogr. A 1032

11 (2004) 193.

12 [26] S. Sentellas, E. Moyano, L. Puignou, M.T. Galcerán, Electrophoresis 24 (2003)

133075.

14 [27] C.A. Groom, A. Halasz, L. Paquet, S. Thioboutot, G. Ampleman, J. Hawari, J.

15 Chromatogr. A $1072(2005) 73$.

16 [28] K. Otsuka, C.J. Smith, J. Grainger, J.R. Barr, D.G. Patterson, N. Tanaka, S. Terabe,

17 J. Chromatogr. A 817 (1998) 75.

18 [29] A.C. Servais, M. Fillet, R. Mol, G.W. Somsen, P. Chiap, G.J. de Jong, J. 19 Crommen, J. Pharm. Biomed. Anal. 40 (2006) 102.

20 [30] H.T. Feng, L.L. Yuan, S.F.Y. Li, J. Chromatogr. A 1014 (2003) 83.

21 [31] L. Goodwin, J.R. Startin, B.J. Keely, D.M. Goodall, J. Chromatogr. A 1004 (2003) 22107.

23 [32] J. Suomi, S.K. Wiedmer, M. Jussila, M.L. Riekkola, Electrophoresis 22 (2001) 242580.

25 [33] J. Suomi, S.K. Wiedmer, M. Jussila, M.L. Riekkola, J. Chromatogr. 970 (2002) 
287.

[34] D. Arráez-Román, S. Cortacero-Ramírez, A. Segura-Carretero, J.A. Martín-Lagos

Contreras, A. Fernández-Gutiérrez, Electrophoresis 27 (2006) 2197.

[35] A. Juan-García, G. Font, Y. Picó, Electrophoresis 27 (2006) 2240.

[36] S.A. Scheppers and J. Pawliszyn, Solid-phase microextraction theory, in S.A.

Scheppers Wercinski, Ed., Solid-phase microextraction: A Practical Guide, Marcel

Dekker, New York, 1999.

[37] C.W. Wang, J. Pawliszyn, Anal. Commun. 35 (1998) 353.

[38] A.L. Nguyen, J.H.T. Luong, Anal. Chem. 69 (1997) 1726.

[39] R. Rodríguez, J. Mañes, Y. Picó, Anal. Chem. 75 (2003) 452.

[40] J. Hernández-Borges, M.A. Rodríguez-Delgado, F.J. García-Montelongo, A. Cifuentes, Electrophores is 25 (2004) 2065.

[41] E. Baltussen, H.G. Janssen, P. Sandra, C.A. Cramers, J. High Resol. Chromatogr. 20 (1997) 385.

[42] R. Eis ert, J. Pawliszyn, Anal. Chem. 69 (1997) 3140.

[43] M. Herrero, D. Arráez-Román, A. Segura, E. Kenndler, B. Gius, M.A. Raggi, E. Ibañez, A. Cifuentes, J. Chomatogr. A 1084 (2005) 54.

[44] C. Simó, M. Herrero, C. Neusuß, M. Pelzing, E. Kenndler, C. Barbas, E. Ibañez, A. Cifuentes, Electrophores is 26 (2005) 2674.

[45] M. Herrero, C. Simó, E. Ibañez, A. Cifuentes, Electrophoresis 26 (2005) 4215.

[46] M. Herrero, P.J. Martín-Álvarez, F.J. Señorans, A. Cifuentes, E. Ibañez, Food Chem. 93 (2005) 417.

[47] S. Sturm, E.M. Strasser, H. Stuppner, J. Chromatogr. A 1112 (2006) 331-338.

[48] E.L. Edwards, J.A. Rodrigues, J. Ferreira, D.M. Goodall, A.P. Rauter, J. Justino, J. Thomas-Oates, Electrophoresis 27 (2006) 2164. 
1 [49] I. Wahby, D. Arráez-Román, A. Segura-Carretero, F. Ligero, J.M. Caba, A.

2 Fernández-Gutiérrez, Electrophoresis 27 (2006) 2208.

3 [50] M. Valcárcel, L. Arce, A. Ríos, J. Chromatogr. A 924 (2001) 3.

4 [51] M. Miró, E.H. Hansen, Trends Anal. Chem. 25 (2006) 267.

5 [52] B. Santos, B.M. Simonet, A. Ríos, M. Valcárcel, Electrophoresis 25 (2004) 3427.

$6 \quad$ [53] V. Camel, Analyst 126 (2001) 1182.

7 [54] G. Xiong, X. He, Z. Zhang, Anal. Chim. Acta 413 (2000) 49.

8 [55] C. Sparr Eskilsson, E. Björklund, J. Chromatogr. A 902 (2000) 227.

9 [56] S. Jayaraman, R.J. Pruell, R. McKinney, Chemosphere 44 (2001) 181.

10 [57] V. Van Lierde, C. C. Chéry, N. Roche, S. Monstrey, L. Moens, F. Vanhaecke, 11 Anal. Bioanal. Chem. 384 (2006) 378.

$12\lceil 58\rceil$ W.C. Sung, H. Makamba, S.H. Chen, Electrophoresis 26 (2005) 1783.

13 [59] P. Lindberg, A.P. Dahlin, S.K. Bergström, S. Thorslund, P.E. Andrén, F. 14 Nikolajeff, J. Bergquist, Electrophoresis 27 (2006) 2075.

15 [60] S. Thorslund, P. Lindberg, P.E. Andrén, F. Nikolajeff, J. Bergquist, Electrophoresis $16 \quad 26(2005) 4674$.

17 [61] A.P. Dahlin, M. Wetterhall, G. Liljegren, S.K. Bergström, M. Djovic, J. Ljung, O.

18 Berglund, N. Ed enwall, K.E. Markides, B. Langstrom, Analyst 230 (2005) 193.

19 [62] A.P. Dahlin, S.K. Bergström, P.E. Andrén, K.E. Markides, J. Bergquist, Anal. 20 Chem. $77(2005) 5356$.

21 [63] G. Liljegren, A.P. Dahlin, C. Zettersten, J. Bergquist, L. Nyholm, Lab Chip 10 22 (2005) 1008.

23 [64] M. Svedberg, M. Veszelei, J. Axelsson, M. Vangbo, F. Nikolajeff, Lab Chip 4 $24 \quad$ (2004) 322.

25 [65] J.S. Kim, D.R. Knapp, J. Am. Soc. Mass Spectrom. 12 (2001) 463. 
1 [66] J.S. Kim, D.R. Knapp, J. Chromatogr. A 924 (2001) 137.

2 [67] C. Wang, R. Oleschuk, F. Ouchen, J. Li, P. Thibault, D.J. Harrison, Rapid

3 Commun. Mass Spectrom. 14 (2000) 14.

4 [68] S.H. Chen, Y.H. Lin, L.Y. Wang, C.C. Lin, G.B. Lee, Anal. Chem. 74 (2002)

$5 \quad 5146$.

6 [69] J.P. Quirino, S. Terabe, J. Chromatogr. A 902 (2000) 119.

7 [70] Z.K. Shihabi, J. Chromatogr. A 902 (2000) 107.

8 [71] J.B. Kim, S. Terabe, J. Pharm. Biomed. Anal. 30 (2003) 1625.

9 [72] J.P. Quirino, J.B. Kim, S. Terabe, J. Chromatogr. A 965 (2002) 357.

10 [73] N.A. Guzman, Electrophoresis 24 (2003) 3718.

11 [74] M. Petersson, K.G. Wahlund, S. Nilsson, J. Chromatogr. A 841 (1999) 249.

12 [75] Q. Yang, A.J. Tomlinson, S. Naylor, Anal. Chem. 71 (1999) 183A.

13 [76] A.B. Wey, W. Thormann, J. Chromatogr. A 924 (2001) 507.

14 [77] A.B. Wey, W. Thorman, J. Chromatogr. B 770 (2002) 191.

15 [78] O. Núñez, E. Moyano, M.T. Galcerán, J. Chromatogr. A 974 (2002) 243.

16 [79] Y. Yang, R.I. Boysen, MT.W. Hearn, Anal. Chem. 78 (2006) 4752.

17 [80] S.Y. Chang, F.Y. Wang, J. Chromatogr. B 199 (2004) 265.

18 [81] M.A. Friedberg, M. Hinsdale, Z.K. Shihabi, J. Chromatogr. A 701 (1997) 35.

19 [82] Z.K. Shihabi, J. Chromatogr. A 817 (1998) 25.

20 [83] H. Keski-Hynnilä, K. Raanaa, J. Taskinen, R. Kostiainen, J. Chromatogr. B 749

$21 \quad(2000) 253$.

22 [84] L. Ge, J.W.H. Yong, S.N. Tan, E.S. Ong, Electrophoresis 27 (2006) 2171.

23 [85] R. García-Villalba, S. Cortacero-Ramírez, A. Segura-Carretero, J.A. Martín-Lagos

24 Contreras, A. Fernández Gutiérrez, J. Agric. Food Chem. 54 (2006) 5400.

25 [86] E. Balaguer, C. Neussus, Anal. Chem. (2006) in press. 
1 [87] A.D. Zamfir, N. Dinca, E. Sisu, J. Peter-Katalinic, J. Sep. Sci. 29 (2006) 414.

2 [88] S. Amon, A. Plemati, A. Rizzi, Electrophoresis 27 (2006) 1209.

3 [89] C. Li, Z. Chen, D. Wen, J. Zhang, W. Cong, B. Yu, Y. Liao, H. Liu, $4 \quad$ Electrophoresis 27 (2006) 2152.

5 [90] A. Carrasco-Pancorbo, D. Arráez-Román, A. Segura-Carretero, A. Fernández6 Gutiérrez, Electrophoresis 27 (2006) 2182.

7 [91] A. Pitois, L.A. de las Heras, A. Zampolli, L. Menichetti, R. Carlos, G. Lazzerini, L.

8 Cionini, P.A. Salvatori, M. Betti, Anal. Bioanal. Chem. 384 (2006) 751.

9 [92] L. Bindilla, J. Peter-Katalinic, Z. Zamfir, Electrophoresis 26 (2005) 1488.

10 [93] U.L. Peri-Okonny, S.X. Wang, R.J. Stubbs, N.A. Guzmán, Electrophoresis 26

11 (2005) 2652.

12 [94] G. Boatto, M. Nieddu, A. Carta, A. Pau, M. Palomba, B. Asproni, R. Cerri, J. 13 Chomatogr. B 814 (2005) 93.

14 [95] J.L. Edwards, C.N. Chisolm, J.G. Shackman, R.T. Kennedy, J. Chromatogr. A $15 \quad 1106(2006) 80$.

16 [96] S.S. Kannamkumarath, K. Wrobel, R.G. Wuilloud, Talanta 66 (2005) 153.

17 [97] M. Meier, T. Kaiser, A. Herrmann, S. Knueppel, M. Hillmann, P. Koester, T. Danne, H. Haller, D. Fliser, H. Mischak, J. Diab. Complic. 19 (2005) 223. [98] D. Theodorescu, D. Fliser, S. Wittke, H. Mischak, R. Krebs, M. Walden, M. Ross,

20 E. Eltze, O. Bettendorf, C. Wulfing, A. Semjonow, Electrophoresis 26 (2005) 2797.

21 [99] A. Psurek, C. Neusüß, M. Pelzing, G.K.E. Scriba, Electrophoresis 26 (2005) 4368.

22 [100] C. Simó, R. González, C. Barbas, A. Cifuentes, Anal. Chem. 77 (2005) 7709.

23 [101] C. Simó, A. Rizzi, C. Barbas, A. Cifuentes, Electrophoresis 26 (2005) 1432.

24 [102] M. Arias, C. Simó, L.T. Ortiz, M. Mozos-Pascual, C. Barbas, A. Cifuentes, 25 Electrophoresis $26(2005) 2351$. 
1 [103] P. Bednar, B. Papou skova, L. Müller, P. Bartak, J. Stávek, P. Pavlousek, K. Lemr, 2 J. Sep. Sci. 28 (2005) 1291.

3 [104] M. Himmelgbach, C.W. Klampfl, W. Buchberger, J. Sep. Sci. 18 (2005) 1735.

4 [105] C. Simó, C. Elvira, N. González, J. San Román, C. Barbas, A. Cifuentes, $5 \quad$ Electrophoresis 25 (2004) 2056.

$6 \quad$ [106] B. Michalke, J. Chromatogr. A 1050 (2004) 69.

7 [107] U.M. Demelbauer, A. Plematl, L. Kremser, G. Allmaier, D. Josic, A. Rizzi, $8 \quad$ Electrophoresis 25 (2004) 2026.

9 [108] A. Baldacci, J. Caslavska, A.B. Wey, W. Thormann, J. Chromatogr. A 1051 $10 \quad$ (2004) 273.

11 [109] G. Vanhoenacker, F. de l'Escaille, De De Keukeleire, P. Sandra, J. Pharm. $12 \quad$ Biomed. Anal. 34 (2004) 595.

13 [110] H. Safarpour, R. Asiaie, S. Katz, J. Chromatogr. A 1036 (2004) 217.

14 [111] A. Zamfir, D.G. Seidler, E. Schönherr, H. Kresse, J. Peter-Katalinic, 15 Electrophoresis 25 (2004) 2010.

16 [112] S. Wittke, D. Fliser, M. Haubitz, S. Bartel, R. Krebs, F. Hausadel, M. Hillmann, I. 17 Golovko, P. Koester, H. Haller, T. Kaiser, H. Mischak, E.M. Weissinger, J. 18 Chromatogr. A 1013 (2003) 173.

19 [113] K. Vuorensola, H. Sirén, U. Karjalainen, J. Chromatogr. B 788 (2003) 277.

20 [114] E.K. Kindt, S. Kurzyniec, S.C. Wang, G. Kilby, D.T. Rossi, J. Pharm. Biomed. $21 \quad$ Anal. 31 (2003) 893.

22 [115] T. Kaiser, A. Hermann, J.T. Kielstein, S. Wittke, S. Bartel, R. Krebs, F. Hausadel, 23 M. Hillmann, I. Golovko, P. Koester, H. Haller, E.M. Weissinger, D. Fliser, H. 24 Mischak, J. Chromatogr. A 1013 (2003) 157.

25 [116] Y. Iinuma, H. Hermann, J. Chromatogr. A 1018 (2003) 105. 
1 [117] G. Bianco, P. Schmitt-Kopplin, G. De Benedetto, A. Kettrup, T.R.I. Cataldi, 2 Electrophoresis 23 (2002) 2904.

3 [118] J. Caslavska, W. Thormann, J. Chromatogr. B 770 (2002) 207.

4 [119] W. Ahrer, E. Scherwenk, W. Buchberger, J. Chromatogr. A 910 (2001) 69.

5 [120] S. Cherkaoui, K. Bekkouche, P. Christen, J.-L. Veuthey, J. Chromatogr. A 922

$6 \quad(2001) 321$.

7 [121] N.A. Guzmán, J. Chromatogr. B 749 (2001) 197.

8 [122] A.B. Wey, J. Caslav ska, W. Thormann, J. Chromatogr. A 895 (2000) 133.

9 [123] A. Ramseier, S. Siethogg, J. Caslavska, W. Thormann, Electrophoresis 21 (2000)

10380.

11 


\section{$1 \quad$ Figure captions}

2

3 Figure 1.- NSM-CE-UV electropherogram of: A) a standard solution containing ca. 1 $\mathrm{mg} / \mathrm{L}$ of each pesticide and; B) a SPE extract from soy milk sample containing $200 \mu \mathrm{g} / \mathrm{L}$ of each pesticide. Injection: $60 \mathrm{~s}$ at 0.5 psi. Running electrolyte: $24 \mathrm{mM}$ formic acid, 16 $\mathrm{mM}$ ammonium carbonate at $\mathrm{pH}$ 6.4; Total length: $57 \mathrm{~cm}$ (50 cm effective length); Voltage: +23 kV; Temperature: $22^{\circ} \mathrm{C}$. (1) Metosulam; (2) Cloransulam-methyl; (3) Diclosulam; (4) Florasulam; (5) Flumetsulam. C) Extracted ion electropherograms of a soy milk sample containing $200 \mu \mathrm{g} / \mathrm{L}$ of each pesticide analyzed under SPE-NSM-CEESI-MS optimized conditions. Redrawn from [17] with permission.

Figure 2.- (a) An on-line PF-MEKC-ESI-MS electropherogram of the mass spectrometric data. The capillary was $80 \mathrm{~cm}$ long and applied voltage was $+15 \mathrm{kV}$ (current $10 \mu \mathrm{A}$ ). Sample was injected at $50 \mathrm{mbar}$ pressure for $10 \mathrm{~s}$. The electrolyte solution contained $20 \mathrm{mM}$ ammonium acetate at $\mathrm{pH} 9.2$ and a solution of $100 \mathrm{mM}$ SDS was injected for $200 \mathrm{~s}$ at 50 mbar pressure. The sheath-liquid contained $1 \mathrm{mM}$ lithium acetate dissolved in water-methanol $(50: 50 \mathrm{v} / \mathrm{v})$ and it was pumped to the electrospray interface at $180 \mu \mathrm{L} / \mathrm{min}$. Mass area of 100-600 m/z was scanned. (b) A PF-MEKC-UV electropherogram of the sample of (a). Compounds were detected at $20 \mathrm{~cm}$. Peak assignments: (1) catalpol; (2) ketologanin; (3) verbenalin; (4) loganin; (7) 10-cinnamoyl catalpol. Reprinted from [32] with permission.

Figure 3.- Schematic picture of the PDMS microch ip design. A) Shows the microchip as mounted on the holder in front of the MS. Graphite coated emitter was placed between two brass plates (B) to which the high voltage was applied. Holder (C) was 
1 mounted on an $x y z$-adjustable table for easy alignment of the microchip in front of the 2 TOF-MS orifice. Reprinted from [59] with permission.

3 
Figure
Click here to download high resolution image
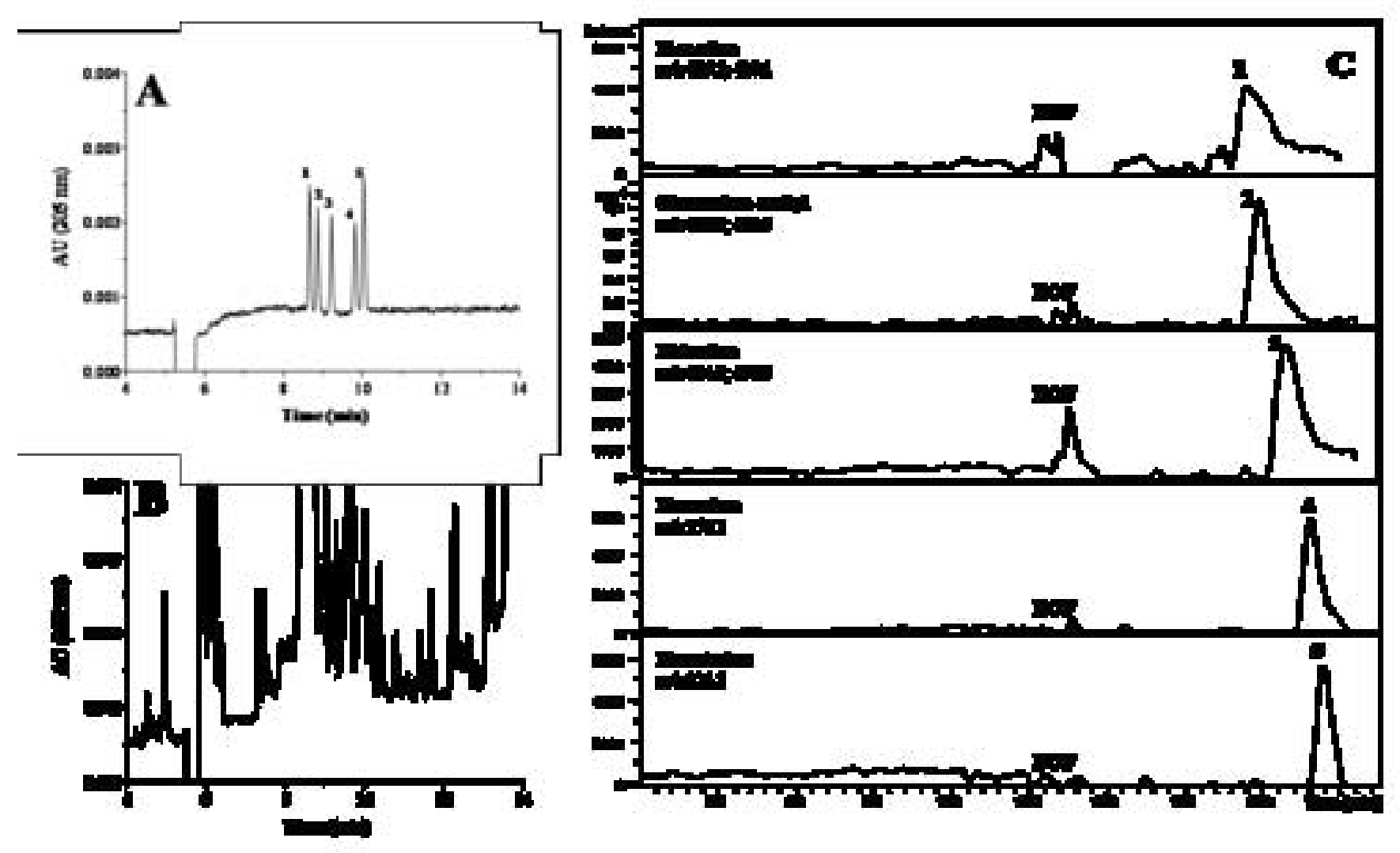

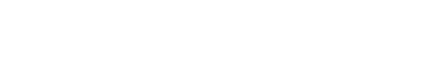

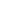


Figure

Click here to download high resolution image
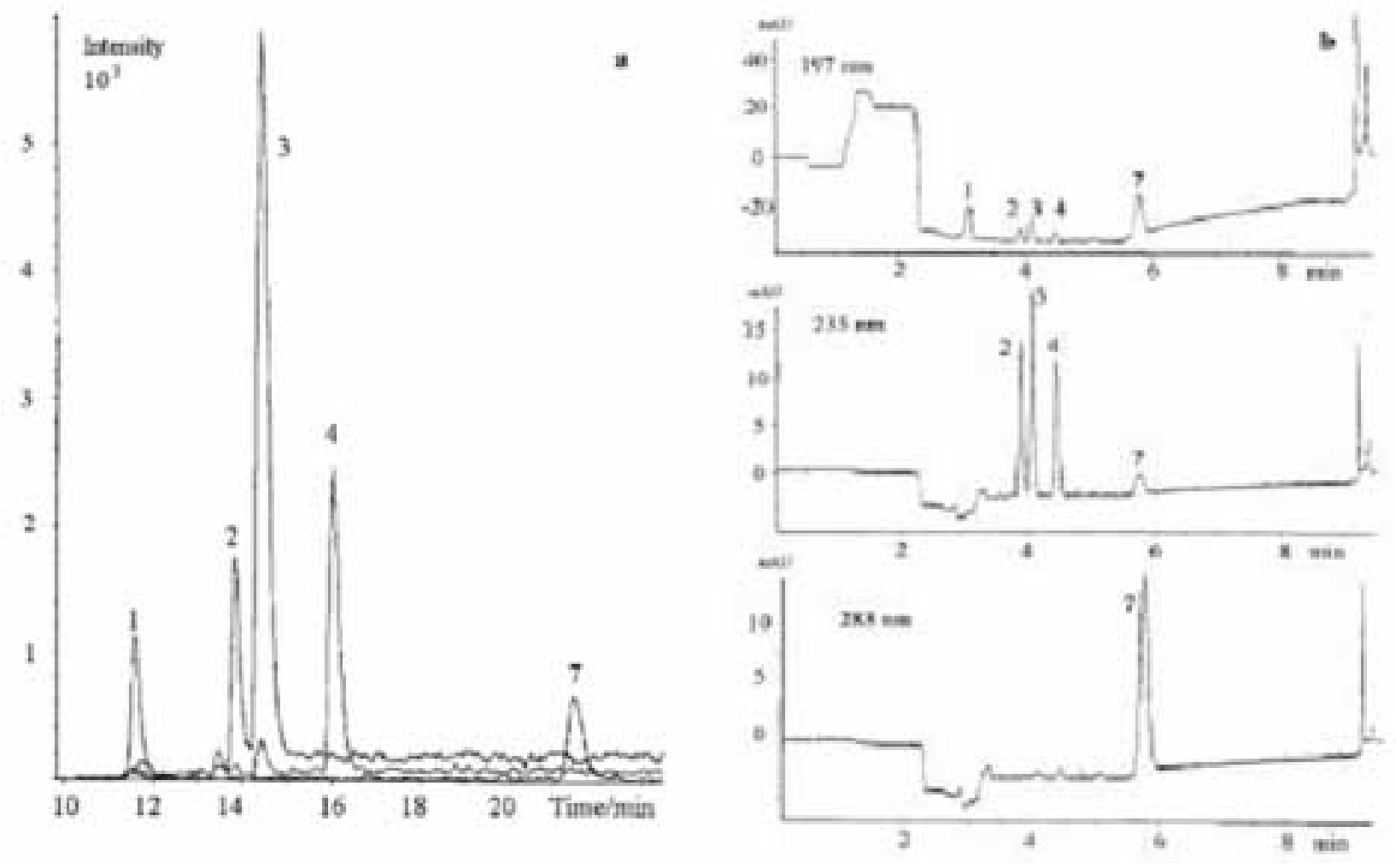
Figure
Click here to download high resolution image

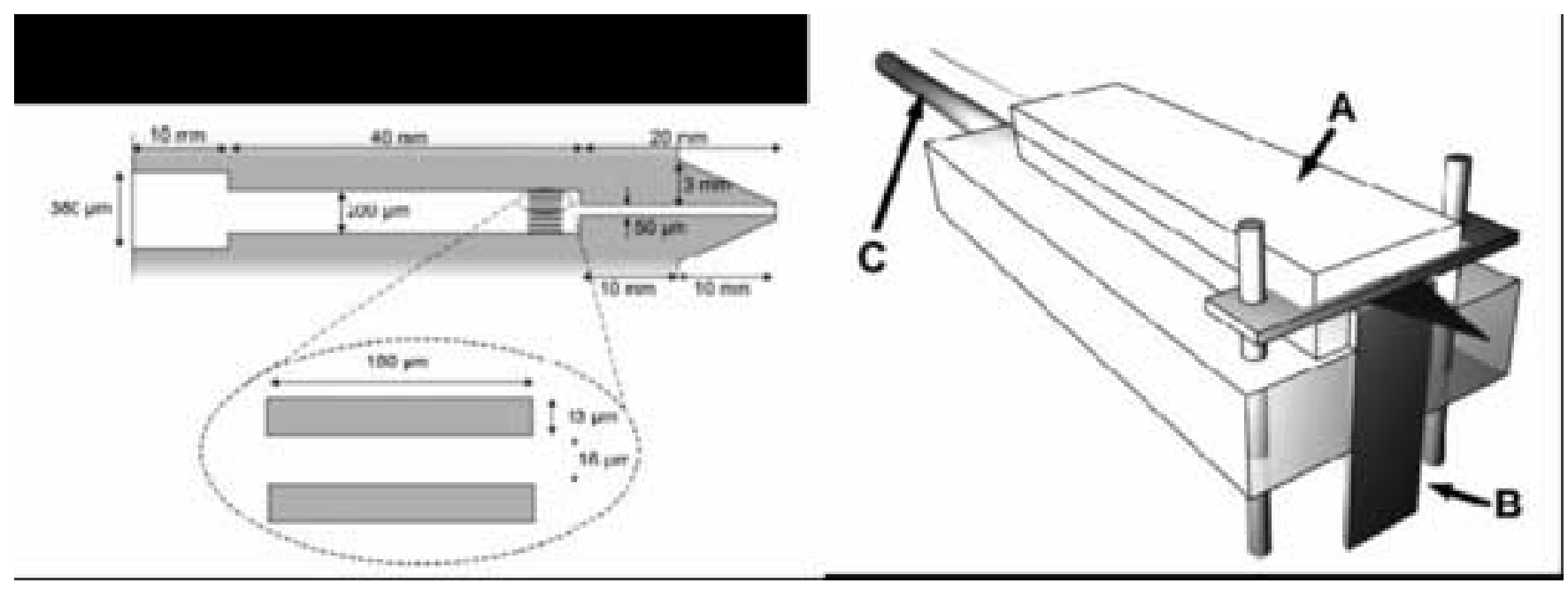

\author{
Click here to download high resolution image
}

.


Table 1.- Some examples of sample treatments, analytes and matrices studied by CE-MS.

\begin{tabular}{|c|c|c|c|c|c|c|c|}
\hline Analyte & Matrix & Treatment & Interface & Analyzer & Buffer & Observations & References \\
\hline $\begin{array}{l}\text { Hops acids, oxidized } \\
\text { derivatives and iso- } \alpha- \\
\text { acids }\end{array}$ & Beer, hops pellets & $\begin{array}{c}\text { Extraction } \\
\text { (ac etone/water) for } \\
\text { hops pellets; SPE for } \\
\text { beer } \\
\end{array}$ & $\begin{array}{c}\text { ESI (sheath-liquid: 2- } \\
\text { propanol:water } 50: 50 \mathrm{v} / \mathrm{v} \text {, } \\
0.1 \% \mathrm{TEA}, 3 \mu \mathrm{L} / \mathrm{min} \text { ) }\end{array}$ & IT & $\begin{array}{c}160 \mathrm{mM}_{\left(\mathrm{NH}_{4}\right)_{2} \mathrm{CO}_{3-}^{-}} \mathrm{NH}_{4} \mathrm{OH} \mathrm{pH} 9\end{array}$ & - & {$[85]$} \\
\hline Glycoproteins & Bovine proteins & $\begin{array}{c}\text { Microcon filtration, } \\
\text { enzymatic } \\
\text { deglyco silation }\end{array}$ & $\begin{array}{c}\text { ESI (she ath-liquid: } 1 \% \\
\text { HOAc in 2-propanol:water } \\
1: 1,4 \mu \mathrm{L} / \mathrm{min} \text { ) }\end{array}$ & IT, TOF & Several buffers & Co ated c apillary & [86] \\
\hline Peptides & $\begin{array}{c}\text { Horse cytoc rome } \mathrm{c} \text { and } \\
\text { myoglobin }\end{array}$ & $\begin{array}{c}\text { Enzymatic digestion, } \\
\text { SPE }\end{array}$ & $\begin{array}{c}\text { ESI (sheath-liquid: } 0.1 \% \\
\mathrm{HCOOH} \text { in } 50 \% \mathrm{MeOH}, 3 \\
\mu \mathrm{L} / \mathrm{min} \text { ) }\end{array}$ & IT & $\begin{array}{c}20 / 40 / 40 \mathrm{ACN}^{2} 100 \mathrm{mM} \\
\mathrm{HCOONH}_{4} \mathrm{pH} 3 / \text { water } \\
\mathrm{v} / \mathrm{v} / \mathrm{v}\end{array}$ & FASI. LOD: $10^{-9} \mathrm{M}$ & [79] \\
\hline Carbohydrates & Urine & - & ESI (sheathless) & QTOF & $\begin{array}{c}50 \mathrm{mM} \mathrm{NH}_{4} \mathrm{Ac}-32 \% \mathrm{NH}_{3} \\
\text { pH } 11 \text { and } 12\end{array}$ & - & [87] \\
\hline Glycopeptides & Plasma & $\begin{array}{l}\text { Lyophilization, } \\
\text { digestion }\end{array}$ & $\begin{array}{c}\text { ESI (sheath-liquid: 2- } \\
\text { propanol-water } 1: 1 \mathrm{v} / \mathrm{v}, \\
0.4 \% \mathrm{HCOOH}, 2.5 \\
\mu \mathrm{L} / \mathrm{min} \text { ) }\end{array}$ & QIT & $\begin{array}{c}50 \mathrm{mM} \mathrm{HCOONH}_{4} \mathrm{pH} 2.7 ; \\
50 \mathrm{mM} \text { triethylammonium } \\
\text { ace tate } \mathrm{pH} 5.0 ; 50 \mathrm{mM} \\
\mathrm{HCOONH}_{4} \mathrm{pH} 8.0\end{array}$ & $\begin{array}{c}\text { MS }^{\mathrm{n}}, \text { off line } \\
\text { MALDI-TOF-MS, } \\
\text { coated capillaries }\end{array}$ & [88] \\
\hline Tobacco-N-nitrosamines & Rabbits' serum & SPE & $\begin{array}{c}\text { ESI (sheath-liquid: } \\
\mathrm{MeOH} \text {-water } 50: 50 \mathrm{v} / \mathrm{v} \text {, } \\
0.5 \% \text { formic acid, } 10 \\
\mu \mathrm{L} / \mathrm{min} \text { ) }\end{array}$ & IT & $\begin{array}{l}75 \mathrm{mM} \text { ammonium formate } \\
(\mathrm{pH} 2.5 \text { ) or citrate }(\mathrm{pH} 2.4)\end{array}$ & - & [89] \\
\hline Cytokinins & Coconut water & SPE & $\begin{array}{l}\text { ESI (sheath-liquid: } 0.3 \% \\
\text { formic acid in } 50 \% \mathrm{v} / \mathrm{v} \\
\text { MeOH:water, } 4 \mu \mathrm{L} / \mathrm{min} \text { ) }\end{array}$ & IT & $\begin{array}{c}25 \mathrm{mM} \text { amonium } \\
\text { formate } / \text { fo rmic acid ( } \mathrm{pH} \\
3.4), 3 \% \mathrm{v} / \mathrm{v} \mathrm{ACN}\end{array}$ & $\begin{array}{l}\mathrm{MS}^{2} \text {, stacking, LOD: } \\
0.05-0.18 \mu \mathrm{M}\end{array}$ & [84] \\
\hline Phenolic compo unds & Virgin olive oil & SPE & $\begin{array}{c}\text { ESI (sheath-liquid: 2- } \\
\text { propanol:water 60:40 v/v, } \\
0.1 \% \mathrm{v} / \mathrm{v} \text { TEA) }\end{array}$ & IT & $\begin{array}{c}60 \mathrm{mM} \mathrm{NH}_{4} \mathrm{OAc} \mathrm{pH} 9.5 \\
\text { with } 5 \% 2 \text {-propanol }\end{array}$ & $\begin{array}{c}\text { Stand ards obtained by } \\
\text { semipreparative } \\
\text { HPLC }\end{array}$ & [90] \\
\hline Neuropeptides & $\begin{array}{c}\text { Physio logic al salt } \\
\text { solution }\end{array}$ & $\begin{array}{l}\text { Microbead-packed } \\
\text { PDMS mic rochip }\end{array}$ & ESI (sheathless) & TOF & $\begin{array}{c}25: 75 \mathrm{v} / \mathrm{v} \text { ACN:10 mM } \\
\text { acetic acid } \\
\end{array}$ & $\begin{array}{c}\text { Microchip; LOD: } 20 \\
\text { fmol } \\
\end{array}$ & [59] \\
\hline Chromium species & Porcine and human skin & $\begin{array}{c}\text { Microwave assisted } \\
\text { digestion }\end{array}$ & ICP & $\mathrm{SF}$ & $\begin{array}{l}50 \mathrm{mM} \text { phosphate buffer } \\
\text { pH } 2.5\end{array}$ & LOD: $6-12 \mu \mathrm{g} / \mathrm{L}$ & [57] \\
\hline $\begin{array}{c}{ }^{10} \mathrm{~B}-\mathrm{BPA} \\
\text { (boronophenylalanine) }\end{array}$ & Cell culture & $\begin{array}{c}\text { Trypsin digestion, } \\
\text { freeze-thawing } \\
\text { cycles- } \\
\text { ultrasonic ation, } \\
\text { ulrafiltration }\end{array}$ & $\begin{array}{c}\text { ESI (sheath-liquid: } 5 \mathrm{mM} \\
\mathrm{NH}_{4} \mathrm{Ac} \text { in } 50 \% \mathrm{v} / \mathrm{v} \\
\mathrm{MeOH}-\text { water, } 10 \mu \mathrm{L} / \mathrm{min} \text { ) }\end{array}$ & IT & $0.5 \mathrm{M} \mathrm{HCOOH}$ & $\begin{array}{c}\text { LOD: } 3 \mu \mathrm{M} \text {; use of } \\
\text { HR-ICP-MS }\end{array}$ & [91] \\
\hline Flavonoids & Plant (Genista tenera) & Soxhlet, LLE, SPE & ESI (she ath-liquid: & IT & Water:2-propanol 95:5, v/v, & $\mathrm{MS}^{2}$ & [48] \\
\hline
\end{tabular}




\begin{tabular}{|c|c|c|c|c|c|c|c|}
\hline & & & $\begin{array}{c}\text { IPA: water 50:50 v/v, } 0.5 \\
\mu \mathrm{L} / \mathrm{min})\end{array}$ & & $\begin{array}{l}10 \mathrm{mM} \text { ammonium } \\
\text { c arbonate (pH 9.25) }\end{array}$ & & \\
\hline $\begin{array}{l}\text { Choline, atropine } \\
\text { Polyphenols, bitter acids } \\
\text { and oxidation products }\end{array}$ & $\begin{array}{l}\text { Hairy root cultures of } \\
\text { Cannabis sativa } L . \\
\text { Hops }\end{array}$ & $\begin{array}{c}\text { Soxhlet } \\
\\
\text { Extraction with } \\
\text { different solvents }\end{array}$ & $\begin{array}{c}\text { ESI (sheath-liquid: } 50: 50 \\
\text { v/v 2-propanol:water, } \\
0.5 \% \text { v/v formic acid } 0.18 \\
\mathrm{~mL} / \mathrm{h} \text { ) } \\
\text { ESI (sheath-liquid: } 60: 40 \\
\text { v/v, 2-propanol:water, } \\
0.1 \% \text { TE A, } 0.28 \mathrm{~mL} / \mathrm{h} \text { ) }\end{array}$ & IT & $\begin{array}{l}20 \mathrm{mM} \mathrm{NH}_{4} \mathrm{OAc}, \mathrm{pH} 8.5 \\
80 \mathrm{mM} \mathrm{NH}_{4} \mathrm{OAc} / \mathrm{NH}_{4} \mathrm{OH} \\
\mathrm{pH} 10.5\end{array}$ & $\begin{array}{c}\text { LOD: } 18 \mathrm{mg} / \mathrm{L} \\
\text { (choline), } 320 \mu \mathrm{g} / \mathrm{L} \\
\text { (atropine) } \\
\text { Carac terization of the } \\
\text { methanolic extract of } \\
\text { hops }\end{array}$ & [49] \\
\hline Quinolone residues & Chicken, fish & $\begin{array}{c}\text { Solvent extraction, } \\
\text { SPE }\end{array}$ & $\begin{array}{c}\text { ESI (she ath-liquid: } 60 \mathrm{mM} \\
\left(\mathrm{NH}_{4}\right)_{2} \mathrm{CO}_{3}, \mathrm{pH} 9.2,10 \\
\mu \mathrm{L} / \mathrm{min})\end{array}$ & QIT & $60 \mathrm{mM}\left(\mathrm{NH}_{4}\right)_{2} \mathrm{CO}_{3}, \mathrm{pH} 9.2$ & $\mathrm{MS}^{\mathrm{n}}, \mathrm{LOD}: 20 \mathrm{ng} / \mathrm{g}$ & [35] \\
\hline Glycopeptides & Urine & $\begin{array}{l}\text { Gel filtration } \\
\text { chro matography, } \\
\text { anion exchange } \\
\text { chromatography }\end{array}$ & ESI (sheathless) & QTOF & $\begin{array}{c}0.1 \mathrm{M} \mathrm{HCOOH} \text { in } \\
\mathrm{MeOH}: \text { water } 6: 4, \mathrm{v} / \mathrm{v}\end{array}$ & $\begin{array}{c}\text { LOD: } 0.05-0.25 \\
\mathrm{mg} / \mathrm{mL}\end{array}$ & [92] \\
\hline Iso quinoline alkalo ids & $\begin{array}{l}\text { Herb(Fu maria officinalis) } \\
\text { and phytopharmace uticals }\end{array}$ & $\begin{array}{l}\text { Soxhlet, LLE, SPE, } \\
\text { ultrasounds }\end{array}$ & $\begin{array}{c}\text { ESI (she ath-liquid: } \\
\text { isopropanol-water 1:1 v/v, } \\
3 \mu \mathrm{L} / \mathrm{min} \text {.) }\end{array}$ & IT & $\begin{array}{l}\text { ACN-MeOH 9:1 v/v, } 60 \\
\mathrm{mM} \mathrm{NH}_{4} \mathrm{O} \mathrm{Ac} \text { and } 2.2 \mathrm{M} \\
\text { HOAc }\end{array}$ & $\mathrm{MS}^{2}$ & [47] \\
\hline $\begin{array}{l}\text { Nitroaromatic and cyclic } \\
\text { nitramines }\end{array}$ & $\begin{array}{l}\text { Rosmarinus officinalis } L \text {. } \\
\text { Soil and marine sediment }\end{array}$ & $\begin{array}{c}\text { PLE } \\
\text { ACN sonication }\end{array}$ & $\begin{array}{c}\text { ESI (sheath-liquid: 2- } \\
\text { propanol-water } 60: 40 \mathrm{v} / \mathrm{v} \text {, } \\
0.1 \% \mathrm{v} / \mathrm{v} \text { TEA; } 0.24 \mathrm{~mL} / \mathrm{h} \text { ) } \\
\text { ESI (sheath-liquid: } 100 \% \\
\text { ACN, } 6 \mu \mathrm{L} / \mathrm{min} \text { ) }\end{array}$ & QIT & $\begin{array}{c}40 \mathrm{mM} \mathrm{NH}_{4} \mathrm{OAc} / \mathrm{NH}_{4} \mathrm{OH} \\
\text { pH } 9 \\
10 \mathrm{mM} \mathrm{SB}^{-} \beta-\mathrm{CD}-10 \mathrm{mM} \\
\mathrm{NH}_{4} \mathrm{OAc}(\mathrm{pH} 6.9)\end{array}$ & LOD: $0.025-0.5 \mathrm{mg} / \mathrm{L}$ & {$[27]$} \\
\hline Caffeine and metabolites & Urine & SPE & $\begin{array}{c}\text { ESI (sheath-liquid: } \\
\mathrm{MeOH}-\text { water-HCOOH } \\
79.7: 19.8: 0.5 \mathrm{v} / \mathrm{v} / \mathrm{v}, 0.5 \\
\mathrm{~mL} / \mathrm{min} \text { ) }\end{array}$ & Q & $\begin{array}{c}50 \mathrm{mM}\left(\mathrm{NH}_{4}\right)_{2} \mathrm{CO}_{3}, \mathrm{pH} \\
11.0\end{array}$ & - & {$[93]$} \\
\hline Pesticide residues & Peaches and nectarines & $\begin{array}{c}\text { Solvent extraction, } \\
\text { SPE }\end{array}$ & $\begin{array}{l}\text { ESI (sheath-liquid: } 0,3 \mathrm{M} \\
\mathrm{NH}_{4} \mathrm{OAc}-\mathrm{HOAc}, \mathrm{pH} 4, \text { in } \\
10 \% \mathrm{MeOH}, 5 \mu \mathrm{L} / \mathrm{min} \text { ) }\end{array}$ & QIT & $\begin{array}{c}0.3 \mathrm{M} \mathrm{NH}_{4} \mathrm{OAc}-\mathrm{HOAc}, \mathrm{pH} \\
4, \text { in } 10 \% \mathrm{MeOH}\end{array}$ & $\begin{array}{l}\mathrm{MS}^{3}, \text { LOQ: } 0.001-0.2 \\
\mathrm{mg} / \mathrm{kg}\end{array}$ & {$[24]$} \\
\hline Salbutamol enantiomers & Human urine & SPE & $\begin{array}{l}\text { ESI (sheath-liquid: ACN- } \\
\text { water } 75 / 25 \mathrm{v} / \mathrm{v}, 0.1 \% \\
\mathrm{HCOOH}, 2.5 \mu \mathrm{l} / \mathrm{min} \text { ) }\end{array}$ & IT & $\begin{array}{c}10 \mathrm{mM} \mathrm{HCOONH}_{4} \text { and } 15 \\
\text { mM HDAS- } \beta \text {-CD in } \\
\mathrm{MeOH}, 0.75 \mathrm{M} \mathrm{HCOOH}\end{array}$ & LOQ: $18-20 \mathrm{ng} / \mathrm{mL}$ & {$[29]$} \\
\hline $\begin{array}{l}\text { Me thylenedio xy-derivates } \\
\text { of amphe tamine }\end{array}$ & Urine & SPE & $\begin{array}{l}\text { ESI (sheath-liquid: ACN- } \\
\text { water-HOAc 50:49.5:0.5) }\end{array}$ & IT & $\begin{array}{c}50 \mathrm{mM} \mathrm{NH}_{4} \mathrm{OAc} / \mathrm{HOAc} \\
\mathrm{pH} 4.5 \\
\end{array}$ & $\begin{array}{c}\text { LOD: } 0.31-4.29 \\
\mathrm{ng} / \mathrm{mL} \\
\end{array}$ & [94] \\
\hline Pesticides & Soy milk & SPE & $\begin{array}{c}\text { ESI (she ath-liquid: } \\
\text { ACN } / \text { water } 82.5: 17.5 \mathrm{v} / \mathrm{v} \\
2 \% \text { TEA, } 0.35 \mathrm{~mL} / \mathrm{h} \text { ) }\end{array}$ & IT & $\begin{array}{l}24 \mathrm{mM} \mathrm{HCOOH} \text { and } 16 \\
\mathrm{mM}\left(\mathrm{NH}_{4}\right)_{2} \mathrm{CO}_{3}, \mathrm{pH} 6.4\end{array}$ & LOD: $74-150 \mu \mathrm{g} / \mathrm{L}$ & {$[17]$} \\
\hline Phosphorylated and acidic & Escherichia coli DH5- $\alpha$ & Cell lisation & ESI (sheathless) & QIT & $80 \% \mathrm{v} / \mathrm{v} 20 \mathrm{mM} \mathrm{NH}_{4} \mathrm{OAc}$ & $\mathrm{MS}^{2}$ & [95] \\
\hline
\end{tabular}




\begin{tabular}{|c|c|c|c|c|c|c|c|}
\hline me tabolites in prokaryotes & & & & & $\begin{array}{c}\text { pH } 9.5 \text { and } 20 \% \mathrm{v} / \mathrm{v} 2- \\
\text { propanol }\end{array}$ & & \\
\hline Selenium & $\begin{array}{l}\text { Nuts (Bertholletia } \\
\text { excelsa) }\end{array}$ & $\begin{array}{l}\text { Defatted nuts } \\
\text { hydrolization }\end{array}$ & ICP & $\bar{Q}$ & $\begin{array}{c}\text { Ammonium pH } 9.25 \text { with } \\
2 \% \mathrm{v} / \mathrm{v} \text { OFM anion-BT }\end{array}$ & $\begin{array}{c}\text { Study of the } \\
\text { association of } \\
\text { selenium to proteins; } \\
\text { electrokinetic } \\
\text { injections }\end{array}$ & [96] \\
\hline Polypeptides and proteins & Urine & SPE, lyophilization & $\begin{array}{l}\text { ESI (sheath-liquid: } 30 \% \\
\mathrm{MeOH}, 0.5 \% \mathrm{HCOOH})\end{array}$ & TOF & $\begin{array}{c}30 \% \mathrm{MeOH}, 0.5 \% \\
\mathrm{HCOOH}, 69.5 \% \text { water }\end{array}$ & $\begin{array}{l}\text { Identification of } \\
\text { protein pattern in } \\
\text { Type } 1 \text { diabetics }\end{array}$ & [97] \\
\hline Neuropeptides & - & SPE & ESI (sheathless) & TOF & $25: 75$ ACN:1 0 mM HOAc & $\begin{array}{l}\text { PDMS microchip, } \\
\text { LOD: } 0.1 \mu \mathrm{g} / \mathrm{ml}\end{array}$ & [62] \\
\hline Polypeptides & Human urine & $\begin{array}{c}\text { Ultrafiltration, SPE, } \\
\text { lyophilization }\end{array}$ & $\begin{array}{l}\text { ESI (sheath-liquid: } 30 \% \\
\text { v/v isopropanol, } 0.4 \% \mathrm{v} / \mathrm{v} \\
\text { HCOOH, } 2 \mu \mathrm{L} / \mathrm{min} \text { ) }\end{array}$ & TOF & $\begin{array}{c}20 \% \text { ACN, } 0.25 \mathrm{M} \\
\mathrm{HCOOH}, 79.5 \% \text { water }\end{array}$ & $\begin{array}{l}\text { Indentific ation of } \\
\text { polypeptides and } \\
\text { patterns of } \\
\text { polypeptides specific } \\
\text { for prostate cancer } \\
\end{array}$ & [98] \\
\hline $\begin{array}{l}\text { Lipophiclic peptaibol } \\
\text { al amethicin }\end{array}$ & $\begin{array}{l}\text { Culture broth of } \\
\text { Trichoderma viride }\end{array}$ & Preparative HPLC & $\begin{array}{l}\text { ESI (sheath-liquid: 2- } \\
\text { propanol:water 1:1 v/v; } \\
1 \% \mathrm{HCOOH} ; 4 \mu \mathrm{L} / \mathrm{min} \text { ) }\end{array}$ & IT, TOF & $\begin{array}{c}\text { NACE: } 12.5 \mathrm{mM} \\
\mathrm{HCOONH} \mathrm{N}_{4} \text { in } \mathrm{MeOH} \\
\left(\mathrm{pH}_{\text {app }}=7.4\right) \\
\text { Aqueous: } 25 \mathrm{mM} \text { borate } \\
\text { pH } 11.0\end{array}$ & $\mathrm{MS}^{\mathrm{n}}$ & [99] \\
\hline Peptide mixture & - & Digestion & $\begin{array}{c}\text { ESI (sheath-liquid: } \\
\text { MeOH-water 50:50 v/v; } \\
0.05 \mathrm{v} / \mathrm{v} \text { HCOOH, } 4 \\
\mu \mathrm{L} / \mathrm{min} \text { ) }\end{array}$ & IT & $0.9 \mathrm{M} \mathrm{HCOOH}, \mathrm{pH} 2$ & $\begin{array}{l}\text { Peptide modeling; } \\
\text { charac terization of } \\
\text { enzyme cleavage } \\
\text { patterns. } \mathrm{MS}^{2}\end{array}$ & {$[100]$} \\
\hline Amino acids & Orange juice & $\begin{array}{l}\text { Derivatization with } \\
\text { FITC and DNS }\end{array}$ & $\begin{array}{c}\text { ESI (she ath-liquid: } \\
\text { MeOH-water 50:50 v/v } \\
\text { with } 25 \% 100 \mathrm{mM} \mathrm{NH}_{4} \mathrm{Ac} \\
\text { pH } 65 \mathrm{mM} \beta-\mathrm{CD} ; 3.5 \\
\mu \mathrm{L} / \mathrm{min} \text { ) }\end{array}$ & IT & $\begin{array}{c}100 \mathrm{mM} \mathrm{NH}_{4} \mathrm{Ac} \mathrm{pH} 65 \\
\mathrm{mM} \beta-\mathrm{CD}\end{array}$ & Capillary co ating, & {$[101]$} \\
\hline $\begin{array}{l}\gamma \text {-glutamyl-S-ethenyl- } \\
\text { cysteine (GEC) }\end{array}$ & $\begin{array}{c}\text { Vicia narboneusis } L . \\
\text { seeds }\end{array}$ & $\begin{array}{l}\text { Solvent extraction } \\
\text { stirring or } \\
\text { ultrasounds }\end{array}$ & $\begin{array}{c}\text { ESI (she ath-liquid: } \\
\mathrm{MeOH}-\text { water 50:50 v/v } \\
0.1 \% \mathrm{v} / \mathrm{v} \text { HOAc, } 3 \\
\mu \mathrm{L} / \mathrm{min})\end{array}$ & IT & $20 \mathrm{mM} \mathrm{NH}_{4} \mathrm{HCO}_{3} \mathrm{pH} 7$ & LOD: $0.021 \mathrm{mg} / \mathrm{mL}$ & {$[102]$} \\
\hline
\end{tabular}




\begin{tabular}{|c|c|c|c|c|c|c|c|}
\hline Proteins & $\begin{array}{l}\text { Spirulina platen sis } \\
\text { microalga }\end{array}$ & $\begin{array}{c}\text { Sonication, PLE, } \\
\text { ultrafiltration, } \\
\text { precipitation- } \\
\text { dialysis-fre eze drying }\end{array}$ & $\begin{array}{l}\text { ESI (sheath-liquid: water- } \\
\text { 2-propanol } 75: 25 \mathrm{v} / \mathrm{v}, 0.5 \\
\% \mathrm{v} / \mathrm{v} \text { HOAc, } 6 \mu \mathrm{L} / \mathrm{min} \text { ) }\end{array}$ & IT & $\begin{array}{c}40 \mathrm{mM} \text { ammonium } \\
\text { hydrogen carbonate } \mathrm{pH} 7.8 \\
\text { in water-ACN-2-propanol } \\
45: 50: 5 \% \mathrm{v} / \mathrm{v} / \mathrm{v}\end{array}$ & PLE optimization & {$[45]$} \\
\hline Proteins & $\begin{array}{l}\text { Spirulina platen sis } \\
\text { microalga }\end{array}$ & $\begin{array}{l}\text { Sonication, PLE, } \\
\text { freeze drying }\end{array}$ & $\begin{array}{l}\text { ESI (sheath-liquid: water- } \\
\text { 2-propanol } 75: 25 \mathrm{v} / \mathrm{v}, 0.5 \\
\% \mathrm{v} / \mathrm{v} \text { HOAc, } 6 \mu \mathrm{L} / \mathrm{min} \text { ) }\end{array}$ & IT, TOF & $\begin{array}{c}40 \mathrm{mM} \text { ammonium } \\
\text { hydrogen carbonate } \mathrm{pH} 7.8 \\
\text { in water:ACN 2-propanol } \\
45: 50: 5 \% \mathrm{v} / \mathrm{v} / \mathrm{v}\end{array}$ & - & {$[44]$} \\
\hline Anthocyanins & Wine and wine musts & SPE & $\begin{array}{c}\text { ESI (sheath-liquid: } \\
\text { MeOH:water } 80: 20 \text {, } \\
0.25 \% \text { v/v HOAc) }\end{array}$ & IT & $\begin{array}{c}200 \mathrm{mM} \\
\text { monochloroacetate- } \\
\text { ammonium, pH } 2 \text { or } 200 \\
\text { mM borate-ammnonium, } \\
\text { pH } 9\end{array}$ & $\begin{array}{l}\text { Acidic and basic } \\
\text { BGE. LOD: } 0.8-1.5 \\
\text { mg/L (acidic); } 4-10 \\
\text { mg/L (basic) }\end{array}$ & {$[103]$} \\
\hline Antidepressants & Water & SPE & $\begin{array}{c}\text { ESI (sheath-liquid: } 5 \mathrm{mM} \\
\mathrm{HCOONH}_{4} \text { in } 8: 2 \\
\text { iso propanol/water, } 1 \\
\mu \mathrm{L} / \mathrm{min} \text { ) }\end{array}$ & QTOF & $\begin{array}{c}1.5 \mathrm{M} \mathrm{HCOOH}, 50 \mathrm{mM} \\
\mathrm{HCOONH}_{4} \text { in ACN/water } \\
85: 15\end{array}$ & LOD: $22-280 \mu \mathrm{g} / \mathrm{L}$ & {$\left[\begin{array}{lll}1 & 04]\end{array}\right.$} \\
\hline Basic proteins & $\begin{array}{l}\text { Chicken and turkey egg } \\
\text { white, wine, minced meat }\end{array}$ & $\begin{array}{c}\text { Lyophilization (white } \\
\text { egg); meat } \\
\text { (homogenizaiton and } \\
\text { buffer extraction) } \\
\end{array}$ & $\begin{array}{c}\text { ESI (she ath-liquid: } \\
\mathrm{MeOH}: \text { water } 50: 50 \mathrm{v} / \mathrm{v} \text {, } \\
0.05 \% \mathrm{v} / \mathrm{v} \text { HOAc } 4 \\
\mu \mathrm{L} / \mathrm{min} \text { ) }\end{array}$ & IT & $\begin{array}{c}75 \text { mM NHOAc/ HOAc, } \\
\text { pH } 5.5\end{array}$ & $\begin{array}{l}\text { Polymer c apillary } \\
\text { coating; LOD: } 2.9 \\
\text { fmol; addulte ration } \\
\text { detection } \\
\end{array}$ & {$\left[\begin{array}{lll}1 & 05\end{array}\right]$} \\
\hline Manganese & Liver & $\begin{array}{l}\text { Homo ge nization, } \\
\text { liquid nitrogen, } \\
\text { extraction in Tris- } \\
\mathrm{HCl}\end{array}$ & ICP & Q & $10 \mathrm{mM}$ Tris- $\mathrm{HCl} \mathrm{pH} 7.4$ & $\begin{array}{l}\text { Speciation study; } \\
\text { LOD: } 1.1 \mu \mathrm{g} \mathrm{Mn} / \mathrm{L}\end{array}$ & {$\left[\begin{array}{ll}1 & 06\end{array}\right]$} \\
\hline Glycoproteins & Plasma & $\begin{array}{c}\text { Affinity } \\
\text { chromatography, } \\
\text { lyophilization }\end{array}$ & $\begin{array}{c}\text { ESI (sheath-liquid: 2- } \\
\text { propanol/1 M HOAc } 1: 1 \\
\mathrm{v} / \mathrm{v}, 3 \mu \mathrm{L} / \mathrm{min} \text { ) }\end{array}$ & QIT & $1 \mathrm{mM}$ HOAc, $4 \mathrm{M}$ urea & $\begin{array}{l}\text { Characterization of } \\
\text { glyco iso fo rms, } \\
\text { coated capillaries }\end{array}$ & {$\left[\begin{array}{lll}1 & 07]\end{array}\right.$} \\
\hline $\begin{array}{c}\text { Oxycodone phase I and II } \\
\text { metabolites }\end{array}$ & Urine & SPE & $\begin{array}{c}\text { ESI (sheath-liquid: water- } \\
\text { methanol } 1: 1 \mathrm{v} / \mathrm{v}, 1 \% \\
\text { formic acid, } 5.0 \mu \mathrm{L} / \mathrm{min} \text { ) }\end{array}$ & IT & $\begin{array}{c}20 \mathrm{mM} \text { ammonium ace tate } \\
\mathrm{pH} 9\end{array}$ & $\begin{array}{l}\mathrm{MS}^{\mathrm{n}}, \text { computer } \\
\text { simulation of } \\
\text { fragmentation }\end{array}$ & {$[108]$} \\
\hline Benzodiazepines & Urine & SPE & $\begin{array}{c}\text { ESI (sheath-liquid: } \\
\mathrm{MeOH} \text {-water } 80: 20 \mathrm{v} / \mathrm{v}, 2 \\
\mu \mathrm{L} / \mathrm{min} \text { ) }\end{array}$ & IT & $\begin{array}{c}100 \mathrm{mM} \text { formic ac id, } 1 \mathrm{mM} \\
\text { TEA }\end{array}$ & $\begin{array}{c}\mathrm{MS}^{2} \text {, use of } \\
\text { dynamically coated } \\
\text { capillaries (CEo fix); } \\
\text { LOD: } 50-100 \mathrm{ppb}\end{array}$ & {$\left[\begin{array}{lll}1 & 09\end{array}\right]$} \\
\hline Heterocyclic amines & Urine & LLE-SPE & $\begin{array}{c}\text { ESI (she ath-liquid: } \\
\mathrm{MeOH}-20 \mathrm{mM} \mathrm{HCOOH} \\
75: 25,5 \mu \mathrm{L} / \mathrm{min})\end{array}$ & IT & $\begin{array}{c}16 \mathrm{mM} \\
\mathrm{HCOOH} / \mathrm{HCOONH} 440 \\
\mathrm{mM} \mathrm{pH} 4.5,60 \% \mathrm{MeOH}^{2}\end{array}$ & LOD: $0.3-45 \mathrm{ng} / \mathrm{mL}$ & {$[25]$} \\
\hline
\end{tabular}




\begin{tabular}{|c|c|c|c|c|c|c|c|}
\hline Imazamox pesticide & Water & SPE & $\begin{array}{c}\text { ESI (sheath-liquid: } \mathrm{MeOH} \\
\mathrm{HCOONH}_{4}(5 \mathrm{mM}) 50: 50 \\
\mathrm{v} / \mathrm{v}, \mathrm{pH} 3.7,4 \mu \mathrm{L} / \mathrm{min})\end{array}$ & IT & $\begin{array}{c}10 \mathrm{mM} \mathrm{HCOONH}_{4} \text { in } \\
0.01 \% \mathrm{MeOH} \text {-water, } \mathrm{pH} \\
7.0\end{array}$ & LOD: $20 \mathrm{ng} / \mathrm{L}$ & {$\left[\begin{array}{ll}1 & 10]\end{array}\right.$} \\
\hline $\begin{array}{l}\text { Glycosamino glyc an } \\
\text { oligo sacc harides }\end{array}$ & $\begin{array}{l}\text { Human embryonic kidney } \\
293 \text { cells }\end{array}$ & $\begin{array}{c}\text { Dialysis, } \\
\text { lyophilization, } \\
\text { digestion }\end{array}$ & ESI (sheathless) & QTOF & $\begin{array}{l}50 \mathrm{mM} \mathrm{NH}_{4} \mathrm{OAc} \mathrm{pH} 12.0 \\
\text { in water:MeOH 40:60 v/v }\end{array}$ & $\mathrm{MS}^{2}$ & [111] \\
\hline $\begin{array}{l}\text { Serotonin, tryptophan and } \\
\text { 5-hydroxytryptophan }\end{array}$ & Plasma & SPE & $\begin{array}{c}\text { ESI (sheath-liquid: } \\
\mathrm{MeOH} / \mathrm{water} 60: 40 \mathrm{v} / \mathrm{v} \\
0.2 \% \mathrm{HCOOH}, 2 \mu \mathrm{L} / \mathrm{min} \text { ) }\end{array}$ & TOF & $1.5 \% \mathrm{HCOOH}(\mathrm{pH} 2.07)$ & LOD: $0.13-3.23 \mu \mathrm{M}$ & {$[18]$} \\
\hline Pesticides & Fruit juices & SPME & $\begin{array}{c}\text { ESI (sheath-liquid: } \\
\text { isopropanol-water } 65 \% \\
\mathrm{v} / \mathrm{v}, 0.22 \mathrm{~mL} / \mathrm{h} \text { ) }\end{array}$ & IT & $0.3 \mathrm{MHOAc}, \mathrm{pH} 4$ & $\begin{array}{c}\text { Chemometric } \\
\text { optimization. LOD } \\
40-150 \mu \mathrm{g} / \mathrm{L}\end{array}$ & {$[40]$} \\
\hline 9 biogenic amines & Red and white wines & FI system & $\begin{array}{l}\text { ESI (sheath-liquid: 70:30 } \\
\text { v/v MeOH/water, 1.0\% } \\
\mathrm{HCOOH}, 4 \mu \mathrm{L} / \mathrm{min} \text { ) }\end{array}$ & Q & $25 \mathrm{mM}$ citric acid $\mathrm{pH} 2$ & $\begin{array}{c}\text { LOD } 0.018-0.09 \\
\mu \mathrm{g} / \mathrm{mL}\end{array}$ & {$[52]$} \\
\hline Pesticides & $\begin{array}{l}\text { Water, grape, apple, } \\
\text { orange, to mato }\end{array}$ & SPME & $\begin{array}{c}\text { ESI (she ath-liquid: } 32 \mathrm{mM} \\
\mathrm{HCOONH}_{4}-\mathrm{HCOOH} \mathrm{pH} \\
3.1+20 \% \mathrm{MeOH}, 14 \\
\mu \mathrm{L} / \mathrm{min})\end{array}$ & Q & $\begin{array}{c}32 \mathrm{mM} \mathrm{HCOONH}_{4-}^{-} \\
\mathrm{HCOOH} \mathrm{pH} 3.1\end{array}$ & LOQ: $0.02-5 \mathrm{mg} / \mathrm{Kg}$ & [39] \\
\hline $\begin{array}{l}\text { Peptides and proteins } \\
\text { Dopamine and } \\
\text { methoxycatecholamines }\end{array}$ & $\begin{array}{l}\text { Urine } \\
\text { Urine }\end{array}$ & $\begin{array}{l}\text { SPE, lyophilization } \\
\text { Enzymatic } \\
\text { hydrolysis, cation } \\
\text { exchange extraction, } \\
\text { SPE } \\
\end{array}$ & $\begin{array}{c}\text { ESI (sheath-liquid: } 30 \% \\
\text { v/v MeOH, } 0.5 \% \mathrm{v} / \mathrm{v} \\
\mathrm{HCOOH}, 5 \mu \mathrm{l} / \mathrm{min} \text { ) } \\
\text { ESI (she ath-liquid: } \\
\mathrm{MeOH}-w a t e r 80: 20 \mathrm{v} / \mathrm{v}, \\
0.5 \% \mathrm{v} / \mathrm{v} \mathrm{HOAc}, 6 \\
\mu \mathrm{l} / \mathrm{min} \text { ) }\end{array}$ & TOF & $\begin{array}{c}30 \% \mathrm{v} / \mathrm{v} \mathrm{MeOH}, 0.5 \% \mathrm{v} / \mathrm{v} \\
\mathrm{HCOOH}, \mathrm{pH} 2.4 \\
50 \mathrm{mM} \mathrm{NH}_{4} \mathrm{OAc} \mathrm{HOAc} \\
\mathrm{pH} 4\end{array}$ & $\begin{array}{l}\text { Comparison CE-UV, } \\
\text { CE-MS with LC-EC; } \\
\text { LOD: } 0.7-1.4 \mu \mathrm{M}\end{array}$ & {$\left[\begin{array}{ll}1 & 12\end{array}\right]$} \\
\hline Alkaloids & $\begin{array}{l}\text { Herbs (Strychnos pieman, } \\
\text { Radix aconiti praeparata) }\end{array}$ & Ultrasonication & $\begin{array}{l}\text { ESI (sheath-liquid: water- } \\
\text { MeOH } 1: 9 \mathrm{v} / \mathrm{v}, 0.5 \% \\
\text { HOAc, } 3 \mu \mathrm{L} / \mathrm{min} \text { ) }\end{array}$ & QIT & $\mathrm{NH}_{4} \mathrm{OAc}, \mathrm{HOAc}, \mathrm{MeOH}$ & - & {$[30]$} \\
\hline Pesticides & Wheat & $\begin{array}{l}\text { Extraction with } \\
\text { water-ace tone }\end{array}$ & ESI (sheathless) & IT & $\begin{array}{c}1 \mathrm{mM} \mathrm{NH}_{4} \mathrm{Ac} / \mathrm{HOAc}(\mathrm{pH} \\
\text { 6.3) in } \mathrm{MeOH} \text { :water 50:50 } \\
\mathrm{v} / \mathrm{v}\end{array}$ & $\begin{array}{l}\text { Coated capillary; } \\
\text { LOD: } 2.5 \mu \mathrm{M}\end{array}$ & {$[31]$} \\
\hline $\begin{array}{l}\text { Heterocyc lic aromatic } \\
\text { amines }\end{array}$ & Urine & LLE, SPE & $\begin{array}{c}\text { ESI (she ath-liquid: } \\
\text { MeOH:20 mM HCOOH } \\
75: 25, \mathrm{v} / \mathrm{v}, 3 \mu \mathrm{L} / \mathrm{min}\end{array}$ & IT & $\begin{array}{c}16 \mathrm{mM} \\
\mathrm{HCOOH} / \mathrm{HCOONH}_{4}, \mathrm{pH} \\
4.5,60 \% \mathrm{MeOH}\end{array}$ & $\begin{array}{l}\text { FAS I. LOD: } 0.8-21 \\
\text { ng/g }\end{array}$ & {$[26]$} \\
\hline Enantiomeric drugs & Plasma & LLE & $\begin{array}{c}\text { ESI (sheath-liquid: } \\
\text { ACN } / 5 \mathrm{mM} \\
\mathrm{NH}_{4} \mathrm{OAc} / \mathrm{HCOOH} \\
75: 25: 0.1(\mathrm{v} / \mathrm{v}), 2 \mu \mathrm{L} / \mathrm{min})\end{array}$ & TOF & $\begin{array}{c}25 \% \mathrm{MeOH}, 75 \% 5 \mathrm{mM} \\
\mathrm{NH}_{4} \mathrm{OAc}(\mathrm{pH} 6), 1.0 \% \\
\mathrm{HOAc}, 0.3 \% \mathrm{HS}-\beta-\mathrm{CD}\end{array}$ & $\begin{array}{c}\text { Electrokinetic } \\
\text { injection; LOQ: } 10 \\
\mathrm{ng} / \mathrm{mL}\end{array}$ & {$\left[\begin{array}{lll}1 & 14]\end{array}\right.$} \\
\hline Polypeptides & Dialysis fluids, urine, & Anion exhange & ESI (sheath-liquid: $30 \%$ & TOF & $30 \% \mathrm{MeOH}$ and $0.5 \%$ & Polipeptide pattern & [1 15] \\
\hline
\end{tabular}




\begin{tabular}{|c|c|c|c|c|c|c|c|}
\hline & serum & $\begin{array}{l}\text { chromatography, } \\
\text { lyophilization }\end{array}$ & $\begin{array}{c}\mathrm{MeOH}, 0.5 \% \text { HCOOH, } \\
69.5 \% \text { water, pH } 2.3-2.5 \\
10 \mu 1 / \mathrm{min})\end{array}$ & & $\begin{array}{c}\mathrm{HCOOH}, 69.5 \% \text { water, } \mathrm{pH} \\
2.3-2.5\end{array}$ & stablishment & \\
\hline $\begin{array}{l}\text { Substituted methoxy } \\
\text { phenols and aromatic } \\
\text { acids }\end{array}$ & Biomass burning aero so 1 & Filter extract (water) & $\begin{array}{l}\text { ESI (sheath-liquid: water } \\
50 \% 2 \text {-propanol } 50 \% \mathrm{v} / \mathrm{v} \\
3 \mu \mathrm{l} / \mathrm{min} \text { ) }\end{array}$ & IT & 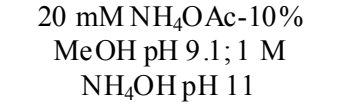 & LOD: $0.1-1.0 \mu \mathrm{M}$ & {$[116]$} \\
\hline $\begin{array}{l}\text { Glycoalkaloids and } \\
\text { relative aglycones }\end{array}$ & Potatoes & $\begin{array}{l}\text { Extraction with } \\
\mathrm{MeOH}\end{array}$ & $\begin{array}{c}\text { ESI (sheath-liquid: } \\
\text { MeOH-water } 1: 1 \mathrm{v} / \mathrm{v}, 1 \% \\
\text { HOAc, } 2.5 \mu \mathrm{L} / \mathrm{min} \text { ) }\end{array}$ & IT & $\begin{array}{c}90: 10 \mathrm{v} / \mathrm{v} \mathrm{MeCN}-\mathrm{MeOH} \\
\text { containing } 50 \mathrm{mM} \\
\mathrm{NH}_{4} \mathrm{OAc} 1.2 \mathrm{M} \mathrm{HOAc}\end{array}$ & $\begin{array}{c}\mathrm{MS}^{2} ; \text { LOD: } 10-50 \\
\mu \mathrm{g} / \mathrm{L}\end{array}$ & {$[117]$} \\
\hline Irioid glyco sides & Plants & Water extraction & $\begin{array}{c}\text { ESI (sheath-liquid: } 1.0 \\
\text { mM lithium ac etate in } \\
\text { water-MeOH 50:50 v/v, } \\
200 \mu \mathrm{L} / \mathrm{h} \text { ) }\end{array}$ & IT & $\begin{array}{c}100 \mathrm{mM} \text { SDS in } 20 \mathrm{mM} \\
\text { ammonium ac etate, } \mathrm{pH} 9.5\end{array}$ & $\begin{array}{l}\text { LOD: } 15-50 \mathrm{mg} / \mathrm{L} ; \\
\text { calculation of water- } \\
\text { micelle partition } \\
\text { coefficients }\end{array}$ & [33] \\
\hline $\begin{array}{l}\text { Procymidone and } \\
\text { thiabenzadole }\end{array}$ & Fruits, ve getables & Sonic ation, SPE & 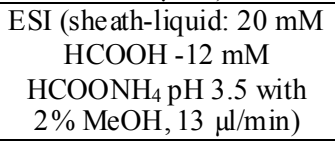 & Q & $\begin{array}{c}20 \mathrm{mM} \mathrm{HCOOH}-12 \mathrm{mM} \mathrm{HCOONH}_{4} \mathrm{pH} 3.5 \text { with } \\
2 \% \mathrm{MeOH}\end{array}$ & $\begin{array}{l}\text { LOQ: } 0.005-0.05 \\
\mathrm{mg} / \mathrm{kg}\end{array}$ & [23] \\
\hline $\begin{array}{l}\text { Oxycodone and major } \\
\text { metabolites }\end{array}$ & Urine & SPE, LLE & $\begin{array}{l}\text { ESI(sheath-liquid: water- } \\
\text { methano } 150: 50 \mathrm{v} / \mathrm{v}, 1 \% \\
\text { formic acid, } 5 \mu \mathrm{L} / \mathrm{min}\end{array}$ & IT & $\begin{array}{c}25 \mathrm{mM} \text { ammonium ace tate } \\
\text { pH } 9\end{array}$ & $\begin{array}{l}\mathrm{MS}^{\mathrm{n}}, \text { hydrodinamic } \\
\text { injection (LOD:10- } \\
300 \mathrm{ng} / \mathrm{ml} \text { ) and FASS } \\
\text { (LOD: } 1-50 \mathrm{ng} / \mathrm{ml} \text { ) }\end{array}$ & [77] \\
\hline Catecholamines & Urine & SPE & ESI (sheathless) & QQQ & $\begin{array}{l}\text { Various BGE containing } \\
\mathrm{NH}_{4} \mathrm{OAc} \text {, water, } \mathrm{MeOH}, \\
\text { ethanol, } \mathrm{HOAc} \text {, pro panol }\end{array}$ & LOD: $0.48-1.30 \mu \mathrm{M}$ & [20] \\
\hline $\begin{array}{l}\text { Catecholamines and } \\
\text { metanephrines }\end{array}$ & Urine & SPE & $\begin{array}{c}\text { ESI (sheath-liquid: } \\
75: 25: 0.1 \\
\mathrm{MeOH} / \mathrm{water} / \mathrm{HOAc} \mathrm{v} / \mathrm{v} \\
1.5 \mu 1 / \mathrm{min} \text { ) }\end{array}$ & TOF & $1 \%$ HOAc $(\mathrm{pH} 2.8)$ & $\begin{array}{l}\text { Electrokinetic } \\
\text { injection }\end{array}$ & [19] \\
\hline Furo semide & Urine & SPE & $\begin{array}{c}\text { ESI (sheath-liquid: } \\
\text { MeOH-water-ammonia } \\
\text { 50:49:1 v/v, } 5 \mu \mathrm{L} / \mathrm{min} \text { ) }\end{array}$ & IT & $\begin{array}{c}20 \mathrm{mM} \mathrm{NH}_{4} \mathrm{OAc} \mathrm{pH} 9 \text { with } \\
\text { TEA }\end{array}$ & $\mathrm{MS}^{2}$ & {$[118]$} \\
\hline Opioids & Urine & SPE, LLE & $\begin{array}{c}\text { ESI (sheath-liquids: } \\
\mathrm{MeOH}-w a t e r 60: 40 \mathrm{v} / \mathrm{v} \\
1 \% \mathrm{HOAc} \text { or } 1 \% \\
\mathrm{HCOOH}, 3 \mu \mathrm{l} / \mathrm{min} \text { or } 5 \\
\mu \mathrm{l} / \mathrm{min} \text { ) }\end{array}$ & IT & $25 \mathrm{mM} \mathrm{NH}_{4} \mathrm{OAc} \mathrm{pH} 9$ & Use of FASS & [76] \\
\hline Drugs & River water & LLE, SPE & $\begin{array}{c}\text { ESI (sheath-liquid: 2- } \\
\text { propanol-water } 80: 20 \mathrm{v} / \mathrm{v} \text {, } \\
0.1 \% \mathrm{v} / \mathrm{v} \text { HOAc or } 0.1 \% \\
\mathrm{v} / \mathrm{v} \text { TE } ; 4 \mu \mu \mathrm{l} / \mathrm{min} \text { ) }\end{array}$ & $\bar{Q}$ & $20 \mathrm{mM} \mathrm{NH}_{4} \mathrm{OAc} \mathrm{pH} 5.1$ & LOD: $18-134 \mu \mathrm{g} / \mathrm{L}$ & [119] \\
\hline
\end{tabular}




\begin{tabular}{|c|c|c|c|c|c|c|c|}
\hline Steroidal alkaloids & $\begin{array}{c}\text { Leaves and seeds } \\
\text { (Solanum sodomaeum), } \\
\text { berries (Solanum } \\
\text { elaeagnifolium) }\end{array}$ & $\begin{array}{l}\text { Extraction with } \\
\text { ethanol and } \mathrm{HCl}\end{array}$ & $\begin{array}{c}\text { ESI (she ath-liquid: } \\
\text { isopropanol-water 50:50 } \\
\text { v/v, 0.5\% HCOOH; } \\
3 \mu \mathrm{l} / \mathrm{min} \text { ) }\end{array}$ & Q & $\begin{array}{c}25 \mathrm{mM} \mathrm{NH}_{4} \mathrm{OAc} \text { and } 1 \mathrm{M} \\
\mathrm{HOAc} \text { in } \mathrm{MeOH}-\mathrm{ACN} \\
20: 80 \mathrm{v} / \mathrm{v}\end{array}$ & LOD: $0.05 \mu \mathrm{g} / \mathrm{mL}$ & {$[120]$} \\
\hline Irioid glyco sides & Plants & Water extraction & $\begin{array}{c}\text { ESI (sheath-liquid: } 1.0 \\
\text { lithium ace tate in water- } \\
\mathrm{MeOH} 50: 50 \mathrm{v} / \mathrm{v}, 200 \\
\mu \mathrm{L} / \mathrm{h} \text { ) }\end{array}$ & IT & $\begin{array}{c}100 \mathrm{mM} \text { SDS in } 20 \mathrm{mM} \\
\mathrm{NH}_{4} \mathrm{OAc}, \mathrm{pH} 9.5\end{array}$ & LOD: $25-50 \mathrm{mg} / \mathrm{L}$ & {$[32]$} \\
\hline $\begin{array}{l}\text { Morphine and related } \\
\text { opiods }\end{array}$ & Urine & LLE, SPE & $\begin{array}{c}\text { ESI (she ath-liquid: } \\
\text { MeOH:water } 60: 40 \mathrm{v} / \mathrm{v} \text {, } \\
1 \% \mathrm{HOAc}, 3 \mu 1 / \mathrm{min} \text { ) }\end{array}$ & IT & $\begin{array}{c}25 \mathrm{mM}^{\text {ammonium ace tate }} \\
\text { and } \mathrm{NH}_{3}(\mathrm{pH} 9)\end{array}$ & $\begin{array}{c}\mathrm{MS}^{3}, \mathrm{LOD} 100-200 \\
\mathrm{ng} / \mathrm{mL}\end{array}$ & {$[14]$} \\
\hline $\begin{array}{c}\text { Gonadotropin-releasing } \\
\text { hormone }\end{array}$ & Serum, urine & Inmunoaffinity CE & $\begin{array}{c}\text { ESI (she ath-liquid: } 20 \mathrm{mM} \\
\text { HOAc in } 50 \% \mathrm{MeOH}, 0.5 \\
\mathrm{ml} / \mathrm{min})\end{array}$ & $\mathrm{Q}$ & $\begin{array}{c}60 \mathrm{~mm} \mathrm{NH}_{4} \mathrm{HCO}_{3} \mathrm{pH} 8.0 \\
1 \% \mathrm{v} / \mathrm{v} \mathrm{ACN}\end{array}$ & - & [121] \\
\hline $\begin{array}{l}\text { Tramadol and its main } \\
\text { phase I metabolite }\end{array}$ & Plasma & LLE & $\begin{array}{c}\text { ESI (she ath-liquid: } \\
\text { Isopropanol-water } 1: 1 \mathrm{v} / \mathrm{v} \text {, } \\
0.5 \% \text { formic acid, } 3 \\
\mu 1 / \mathrm{min} \text { ) }\end{array}$ & Q & $\begin{array}{c}40 \mathrm{mM} \text { ammonium ace tate } \\
\text { buffer, } \mathrm{pH} 4.0, \text { sulfobutyl } \\
\text { ether } \beta-\mathrm{CD}(2.5 \mathrm{mg} / \mathrm{ml})\end{array}$ & Partial filling & {$[12]$} \\
\hline $\begin{array}{l}\text { Etodo lac and its urinary } \\
\text { phase I me tabo lites }\end{array}$ & Urine & LLE & $\begin{array}{c}\text { ESI (sheath-liquid: ACN- } \\
10 \mathrm{mM} \text { ammonium } \\
\text { formate } \mathrm{pH} 3.01: 1 \mathrm{v} / \mathrm{v}, 3 \\
\mu 1 / \mathrm{min})\end{array}$ & IT & $\begin{array}{l}\text { ACN-10 mM ammo nium } \\
\text { formate } \mathrm{pH} 3.01: 1 \mathrm{v} / \mathrm{v}\end{array}$ & $\begin{array}{c}\text { CEC }\left(\mathrm{C}_{18} \text { capillaries }\right) \\
\text { electrokinetic } \\
\text { injection }\end{array}$ & {$[13]$} \\
\hline $\begin{array}{l}\text { Nitroc atechol-type } \\
\text { glucuronides }\end{array}$ & Urine & SPE & $\begin{array}{c}\text { ESI (sheath-liquid: ACN- } \\
20 \mathrm{mM} \text { ammonium ac etate } \\
1: 1 \mathrm{v} / \mathrm{v}, 5 \mu \mathrm{l} / \mathrm{min} \text { ) }\end{array}$ & $\begin{array}{l}Q Q \\
\end{array}$ & $\begin{array}{c}20 \mathrm{mM} \text { ammonium ace tate, } \\
\text { pH } 6.84\end{array}$ & $\begin{array}{c}\text { Stacking, LOD } 7 \\
\mathrm{ng} / \mathrm{mL}\end{array}$ & $\begin{array}{l}83] \\
\end{array}$ \\
\hline $\begin{array}{l}\text { Codeine, dihydrocode ine } \\
\text { and their glucuronides }\end{array}$ & Urine & SPE & $\begin{array}{c}\text { ESI (sheath-liquid: } \\
\text { MeOH-water-ac etic ac id } \\
\text { 69:39:1 v/v/v, } 3 \mu \mathrm{L} / \mathrm{min} \text { ) }\end{array}$ & IT & $25 \mathrm{mM} \mathrm{NH}_{4} \mathrm{OAc} \mathrm{pH} 9$. & $\begin{array}{c}\mathrm{MS}^{2} \text {; LOD: } 100-200 \\
\text { ng/mL }\end{array}$ & [122] \\
\hline $\begin{array}{l}\text { Amphetamine and } \\
\text { designer drugs }\end{array}$ & Urine & LLE & $\begin{array}{c}\text { ESI (sheath-liquid: } \\
\text { MeOH:water:HOAc } \\
\text { 60/39/1 v/v/v, } 3 \mu \mathrm{L} / \mathrm{min} \text { ) }\end{array}$ & IT & $\begin{array}{c}20 \mathrm{mM} \mathrm{NH}_{4} \mathrm{OAc}, 20 \mathrm{mM} \\
\mathrm{HOAc} \mathrm{pH} 4.6\end{array}$ & $\mathrm{MS}^{2}$ & [123] \\
\hline Proteins & - & $\begin{array}{l}\text { In-line digestion } \\
\text { microchip }\end{array}$ & ESI (sheathless) & Q & $\begin{array}{c}10 \mathrm{mM}_{\left(\mathrm{NH}_{4}\right) \mathrm{HCO}_{3}}, 100 \\
\mathrm{mM} \mathrm{HCOOH}^{-}\end{array}$ & - & {$[67]$} \\
\hline
\end{tabular}

